\title{
TEORIA DA FIRMA: COMPORTAMENTO DOS ADMINISTRADORES, CUSTOS DE AGÊNCIA E ESTRUTURA DE PROPRIEDADE
}

\section{RESUMO}

Este artigo integra elementos da teoria da agência, da teoria dos direitos de propriedade e da teoria das finanças para desenvolver uma teoria da estrutura de propriedade da firma. Definimos o conceito de custos de agência, demonstramos a sua relação com a questão da "separação e controle", investigamos a natureza dos custos de agência resultantes da presença de capital de terceiros e capital próprio externo, demonstramos quem arca com esses custos e por quê, e investigamos o ótimo de Pareto para a sua existência. Também fornecemos uma definição de firma e mostramos como a nossa análise dos fatores que influenciam a criação e a emissão de capital de terceiros e os direitos sobre o capital próprio cobre um caso especial do lado da oferta no que se refere à totalidade do problema dos mercados.

\section{Michael $C$. Jensen \\ HBS}

William H. Meckling

(in memoriam)

ABSTRACT This paper integrates elements from the theory of agency, the theory of property rights and the theory of finance to devel op a theory of the owner ship structure of the firm. We define the concept of agency costs, show its relationship to the "separation and control" issue, investigate the nature of the agency costs generated by the existence of debt and outside equity, demonstrate who bears these costs and why, and investigate the Pareto optimality of their existence. We also provide a new definition of the firm, and show how our analysis of the factors influencing the creation and issuance of debt and equity claims is a special case of the supply side of the completeness of markets problem.

PALAVRAS-CHAVE Teoria da agência, custos de agência, estrutura de propriedade, estrutura de capital, direitos de propriedade. KEYWODSAgency theory, agency costs, ownership structure, equity, property rights. 
"Contudo, não se pode esperar que os membros do consel ho dessas empresas (de sociedade anônima por ações), por serem os administradores do dinheiro alheio e não do próprio dinheiro, o protejam com a mesma vigilância atenta que os sócios de uma empresa privada costumam dedicar ao próprio dinheiro. Como os capatazes de um homem rico, eles tendem a se envolver em detal hes não necessariamente visando a honra de seus senhores, e muito facilmente concedem a si mesmos permissão para tanto. A negligência e a profusão, portanto, devem sempre prevalecer, em maior ou menor grau, na administração dos negócios de uma empresa como essa" (SMITH, 1776, p. 700).

\section{INTRODUÇÃO}

\section{Motivação do artigo}

Neste artigo, recorremos aos recentes desenvolvimentos da teoria (1) dos direitos de propriedade, (2) da agência e (3) das finanças para desenvolver uma teoria da estrutura de propriedade ${ }^{1}$ da firma. Além de relacionar el ementos da teoria de cada uma dessas três áreas, a nossa análise lança uma nova luz e conduz a implicações para uma série de questões abordadas pela literatura profissional e popular, como a definição da firma, a "separação entre posse e controle", a "responsabilidade social" do negócio, a definição de uma "função objetiva corporativa", a identificação de uma estrutura de capital ótima, a especificação do conteúdo dos acordos de crédito, a teoria das organizações e 0 lado da oferta no que se refere à totalidade do problema dos mercados.

A nossa teoria ajuda a explicar:

1. por que um empresário ou um administrador de uma firma com uma estrutura financeira mista (incluindo os direitos tanto sobre o capital próprio quanto sobre o capital deterceiros) optará por um conjunto de atividades para a firma de forma que o val or total da firma seja menor que o valor possível se eles fossem seus únicos proprietários e por que esse resultado independe de a firma operar em mercados monopolistas ou competitivos de fatores ou de produtos;

2. por que o seu fracasso em maximizar o valor da firma é perfeitamente consistente com a eficiência;

3. por que a venda das ações ordinárias é uma fonte viável de capital, apesar de os administradores literalmente não maximizarem o valor da empresa;

4. por que já se contava com o capital de terceiros como uma fonte de capital antes de o financiamento por capital de terceiros oferecer qualquer vantagem fiscal sobre o capital próprio;

5. por que ações preferenciais seriam emitidas;

6. por que relatórios contábeis seriam fornecidos voluntariamente aos credores e acionistas e por que auditores independentes seriam envolvidos pela administração para verificar a precisão e a exatidão desses relatórios;

7. por que os credores costumam impor restrições às atividades das firmas a quem concedem empréstimos e por que as próprias firmas são levadas a sugerir a imposição de restrições como essas;

8. por que algumas indústrias são formadas por firmas operadas pelo proprietário cuja única fonte externa de capital consiste em empréstimos;

9. por que indústrias altamente regulamentadas, como companhias de serviços públicos ou bancos, apresentarão razão entre capital de terceiros e capital próprio para níveis equivalentes de risco do que uma empresa não regulamentada comum;

10. por que as análises de títulos podem ser socialmente produtivas mesmo se não aumentarem os retornos do portfólio aos investidores.

\section{Teoria da firma: uma caixa vazia?}

A pesar de a literatura sobre a ciência da economia estar repleta de referências à "teoria da firma", o material geralmente incluído nessa classificação não consiste em uma teoria da firma, mas, na verdade, em uma teoria dos mercados nos quais as firmas são importantes participantes: a firma é uma "caixa preta" manipulada de forma a atender às condições marginais relevantes no que diz respeito a inputs e outputs, maximizando, desta forma, os lucros, ou, mais precisamente, 0 valor presente. Com a exceção de algumas poucas tentativas recentes, contudo, não temos uma teoria que explique como os objetivos conflitantes dos participantes individuais atingem o equilíbrio de forma a gerar esse resultado. As limitações dessa abordagem de "caixa preta" para a firma já foram citadas por Adam Smith eAlfred M arshall, entre outros. Mais recentemente, debates populares e profissionais referentes à "responsabilidade social" das empresas, a separação entre posse e controle e as precipitadas revisões da literatura sobre a "teoria da firma" têm evidenciado um interesse contínuo por essas questões. ${ }^{2}$

Várias importantes tentativas foram feitas nos últimos anos para desenvolver uma teoria da firma por meio da substituição de outros modelos pela maximização de valor ou lucro; cada uma dessas tentativas foi motivada por uma conviç̧ão de que a última tentativa é inadequada para explicar o comportamento dos administradores de 
grandes empresas. ${ }^{3}$ Algumas dessas tentativas de reformulação rejeitam o princípio fundamental do comportamento maximizador além de rejeitaram o model o mais específico da maximização de lucros. Continuamos a empregar a noção do comportamento maximizador por parte de todos os indivíduos na análise que se segue. ${ }^{4}$

\section{Direitos de propriedade}

Uma série independente de pesquisas com importantes implicações para a teoria da firma foi impulsionada pelo trabal ho pioneiro de Coase e ampliada por Alchian, Demsetz e outros. ${ }^{5}$ Furubotn e Pejovich (1972) apresentam um amplo levantamento dessa literatura. A pesar de 0 foco dessa pesquisa ter sido sobre os "direitos de propriedade", ${ }^{6}$ o conteúdo englobado é muito mais abrangente do que o termo sugere. 0 que nos interessa para os problemas abordados neste artigo é que a especificação dos direitos individuais define como os custos e as recompensas serão distribuídos entre os participantes em qualquer organização. Pelo fato de a determinação dos direitos ser, em geral, afetada pelos contratos firmados (tanto os implícitos quanto os explícitos), o comportamento individual nas organizações, incluindo o comportamento dos administradores, dependerá da natureza desses contratos. Neste artigo, nos concentraremos nas implicações comportamentais dos direitos de propriedade especificados nos contratos firmados entre os proprietários e os administradores da firma.

\section{Custos de agência}

Muitos problemas associados à inadequação da teoria atual da firma também podem ser levados em consideração como casos especiais das relações da teoria da agência sobre as quais há uma crescente literatura. ${ }^{7}$ Essa literatura tem sido desenvolvida independentemente dos textos sobre os direitos de propriedade, apesar de as questões de interesse serem similares; as abordagens são, na verdade, al tamente complementares.

Definimos uma relação de agência como um contrato sob o qual uma ou mais pessoas (o(s) principal(is)) emprega uma outra pessoa (agente) para executar em seu nome um serviço que implique a delegação de algum poder de decisão ao agente. Se ambas as partes da relação forem maximizadoras de utilidade, há boas razões para acreditar que o agente nem sempre agirá de acordo com os interesses do principal. 0 principal pode limitar as divergências referentes aos seus interesses por meio da aplicação de incentivos adequados para 0 agente e incorrendo em custos de monitoramento visando a limitar as atividades irregulares do agente. Além disso, em al gumas situações, o principal pagará ao agente para despender recursos (custos de concessão de garantias contratuais) visando a assegurar que 0 agente não promoverá certas ações que prejudicariam o principal ou para assegurar que o principal será recompensado se o agente promover essas ações. Contudo, é em geral impossível para o principal ou o agente manter a relação de agência a um custo zero para assegurar que 0 agente tomará decisões de nível ótimo do ponto de vista do principal. Na maioria das relações de agência, o principal e 0 agente incorrerão em custos positivos de monitoramento e de concessão de garantias contratuais (tanto não pecuniários quanto pecuniários) e, além disso, haverá al gum nível de divergência entre as decisões do agente ${ }^{8}$ e as decisões que maximizariam o bem-estar do principal. 0 equival ente monetário da redução do bem-estar vivenciada pelo principal devido a essa divergência também representa um custo da relação de agência e nos referimos a este último custo como "custo residual". Definimos custos de agência como a soma:

(1) das despesas de monitoramento por parte do principal; 9

(2) das despesas com a concessão de garantias contratuais por parte do agente;

(3) e do custo residual.

Observe também que os custos de agência surgem em qualquer situação que envolva esforço cooperativo (tal qual a co-autoria do presente artigo) por parte de duas ou mais pessoas, mesmo se não houver uma relação principalagente claramente definida. Visto dessa forma, fica claro que a nossa definição de custos de agência e de sua importância para a teoria da firma implica em uma estreita proximidade com o problema da negligência e do monitoramento da produção da equipe, levantado por Alchian e Demsetz (1972) em seu estudo da teoria da firma.

Pelo fato de a relação entre os acionistas e o administrador de uma empresa se encaixar na definição de uma relação pura de agência, não deveria ser uma surpresa descobrir que as questões associadas à "separação entre posse e controle" na empresa moderna de posse pulverizada são intimamente associadas ao problema geral da agência. Demonstramos abaixo que uma explicação do porquê e de como os custos de agência são gerados pela forma corporativa leva a uma teoria da estrutura de propriedade (ou de capital) da firma.

Antes de prosseguirmos, contudo, vale notar a generalidade do problema de agência. 0 problema de induzir um "agente" a se comportar como se ele estivesse maximizando o bem-estar do "principal" é rel ativamente geral. Ele sefaz presente em todas as organizações e em todos os 
esforços cooperativos - em qualquer nível da administração das firmas, ${ }^{10}$ em universidades, em empresas mistas (de sociedade anônima e cooperativa), em cooperativas, em órgãos públicos, em sindicatos e em relações normalmente classificadas como relações de agência, como nas artes cênicas e no mercado imobiliário. A elaboração de teorias para explicar as formas que os custos de agência assumem em cada uma dessas situações ( nas quais as relações contratuais diferem significativamente) e como e por que eles são gerados levará a uma importante teoria das organizações, hoje inexistente no estudo da economia e das ciências sociais em geral. Restringimos a nossa atenção neste artigo a apenas uma pequena parcela desse problema geral - a análise dos custos de agência gerados pelos acordos contratuais entre o proprietário e a al ta administração da empresa.

A nossa abordagem ao problema do agência difere fundamental mente da mai or parte da literatura existente. Essa literatura se concentra quase que exclusivamente nos aspectos normativos da relação de agência; isto é, como estruturar a relação contratual (incluindo incentivos de remuneração) entre o principal e o agente para proporcionar os incentivos apropriados visando a induzir 0 agente a fazer escolhas que maximizarão o bem-estar do principal, considerando a existência de incerteza e monitoramento imperfeito. Concentramos-nos quase exclusivamente nos aspectos positivos da teoria. Em outras palavras, presumimos que esses problemas normativos são solucionados pelos indivíduos e, considerando que apenas ações e obrigações podem ser emitidas na forma de direitos, investigamos os incentivos de cada uma das partes e os elementos envolvidos no estabelecimento do equilíbrio contratual que caracteriza a relação entre 0 administrador (i.e., o agente) da firma e os detentores do capital próprio externo e do capital de terceiros (i.e., os principais).

\section{Alguns comentários gerais sobre a definição da firma}

Ronald Coase (1937), em seu artigo seminal sobre a natureza da firma - "The Nature of the Firm" -, observou que a ciência da economia não possui uma teoria positiva para determinar os vínculos contratuais da firma. Ele caracterizou os vínculos contratuais da firma como a faixa de trocas nas quais o sistema de mercado foi suprimido e a alocação de recursos foi realizada em oposição a mecanismos de autoridade e controle. Ele se concentrou no custo de utilizar os mercados para efetivar os contratos e as trocas e argumentou que as atividades seriam incluídas na firma sempre que os custos de utilização dos mercados fossem mai ores que os custos da utilização da autoridade direta. Alchian e Demsetz (1972) discordaram da noção de que as atividades na firma são governadas pela autoridade e enfatizaram, corretamente, o papel dos contratos como um veículo de trocas voluntárias. Eles enfatizaram o papel do monitoramento em situações nas quais há um input coletivo ou uma produção em equipe. ${ }^{11}$ Simpatizamos com a importância que eles atribuem ao monitoramento, mas acreditamos que a ênfase dispensada por Alchian-Demsetz ao insumo eà produção em conjunto é deveras estreita e, em conseqüência, enganosa. As relações contratuais compõem a essência da firma, não somente com os empregados mas também com fornecedores, clientes, credores etc. 0 problema dos custos de agência e do monitoramento existe para todos esses contratos, independentemente de haver uma produção coletiva no sentido utilizado por AlchianDemsetz; i.e., a produção coletiva só pode explicar uma pequena parcel a do comportamento dos indivíduos associados a uma firma. A análise detal hada dessas questões será reservada para um outro artigo.

É importante reconhecer que a maioria das organizações não passa de ficções legais ${ }^{12}$ que servem como um ponto de conexão para um conjunto de relações contratuais entre indivíduos. Isso inclui empresas, instituições sem fins lucrativos como universidades, hospitais e fundações, organizações mistas (de sociedade anônima e cooperativa), alguns clubes privados e até mesmo órgãos públicos como cidades, estados e o governo federal, empreendimentos públicos como os correios, departamentos de trânsito etc.

A empresa privada, ou firma, é simplesmente uma forma de ficção legal que serve como um ponto de conexão para relações contratuais e que também se caracteriza pela existência de direitos residuais divisíveis dos ativos e fluxos de caixa da organização, que em geral podem ser vendidos sem a permissão dos outros participantes do contrato. A pesar de essa definição da firma apresentar pouco conteúdo tangível, a ênfase na natureza essencialmente contratual das firmas e de outras organizações direciona a atenção a algumas questões fundamentais - por que determinados conjuntos de relações contratuais surgem para vários tipos de organizações, quais são as conseqüências dessas relações contratuais e como elas são afetadas pelas mudanças externas à organização. Visto dessa forma, faz pouco ou nenhum sentido tentar distinguir o que está "dentro" da firma (ou de qualquer outra organização) do que está "fora" dela. Há, na verdade, apenas uma série de relações complexas (i.e., contratos) entre a ficção legal (a firma) e os proprietários do trabalho, dos inputs de material e capital e dos consumidores da produção. ${ }^{13}$ 
Considerar a firma como o ponto de conexão de uma série de relações contratuais entre indivíduos também esclarece que a personal ização da firma implicada por perguntas como "qual deveria ser a função-objetivo da firma" ou "a firma teria ou não uma responsabilidade social" é extremamente enganosa. A firma não é um indivíduo. A firma é uma ficção legal que serve como um foco para um processo complexo no qual os objetivos conflitantes de indivíduos (al guns dos quais podem "representar" outras organizações) atingem um equilíbrio no contexto de relações contratuais. N este sentido, o "comportamento" da firma se assemelha ao comportamento de um mercado; i.e., o resultado de um complexo processo de equilíbrio. Raramente caímos na armadi lha de caracterizar o trigo ou o mercado de ações como um indivíduo, mas costumamos cometer esse erro pensando nas organizações como se fossem pessoas com motivações e intenções próprias. ${ }^{14}$

\section{Visão geral do artigo}

A teoria aqui apresentada será desenvolvida em etapas. As Seções 2 e 4 apresentam anál ises dos custos de agência do capital próprio e do capital de terceiros, respectivamente. Essas seções compõem a base da teoria. A Seção 3 apresenta al gu mas questões não-respondidas referentes à existência da forma corporativa da organização e examina o papel da responsabilidade limitada. A Seção 5 apresenta uma síntese dos conceitos básicos fundamentados nas Seções de 2 a 4 em uma teoria da estrutura de propriedade corporativa que leva em consideração os trade-offs disponíveis ao empresário-administrador entre o capital de terceiros e o capital próprio interno e externo. Algumas qualificações e extensões da análise são discutidas na Seção 6, e a Seção 7 apresenta um breve resumo e as conclusões.

\section{OS CUSTOS DE AGÊNCIA DO ACIONISTA EXTERNO}

\section{Visão geral}

N esta seção, analisaremos o efeito da existência de acionistas externos sobre os custos de agência por meio da comparação do comportamento de um administrador quando ele é proprietário integral (de 100 por cento) dos direitos residuais de uma firma com o seu comportamento quando ele vende uma parte desses direitos a terceiros. Se uma firma de propriedade integral é administrada pel o proprietário, ele tomará decisões operacionais que maximizarão a utilidade para si próprio. Essas decisões envolverão não apenas os benefícios que el e terá com os retornos pecuniários como também a utilidade gerada pel os vários aspectos não pecuniários de suas atividades empreendedoras, como as instalações físicas do escritório, a atratividade do pessoal administrativo, o nível de disciplina dos empregados, o tipo e a quantia de contribuições para a caridade, relações pessoais ("amor", "respeito" etc.) com os empregados, um computador mais do que ótimo, a compra de insumos de produção de amigos etc. 0 mix ótimo (na ausência de impostos) dos vários benefícios pecuniários e não pecuniários é atingido quando a utilidade marginal resultante de uma unidade monetária adicional de gastos (medida líquida de quaisquer efeitos produtivos) for igual a cada item não pecuniário e igual à utilidade marginal resultante de uma unidade monetária adicional de poder de compra depois dos impostos (riqueza).

Se o proprietário-administrador vender direitos sobreo capital próprio da empresa que sejam idênticos aos deles (i.e., participação proporcional nos lucros da firma com responsabilidade limitada), os custos de agência serão gerados pela divergência entre 0 seu interesse e 0 interesse dos acionistas externos, já que el e, neste caso, arcará apenas com uma parcela dos custos de quaisquer benefícios não pecuniários que utilizará para maximizar a sua própria utilidade. Se 0 administrador detiver apenas 95 por cento das ações, ele gastará os recursos até o ponto em que a utilidade marginal gerada pelo gasto de um dólar dos recursos da firma nesses itens será igual à utilidade marginal de 95 centavos de dólar adicionais no poder de compra geral (i.e., a participação do administrador na redução da riqueza), e não igual à utilidade marginal de um dólar. Atividades como essa, por parte do administrador, podem ser limitadas (mas provavelmente não eliminadas) pela alocação de recursos em atividades de monitoramento pelos acionistas externos. Contudo, como mostramos abaixo, o proprietário arcará com todos os efeitos desses custos esperados sobre a riqueza enquanto o mercado de ações se antecipar a esses efeitos. Acionistas minoritários potenciais perceberão que os interesses do proprietárioadministrador divergirão em al gum nível de seus próprios interesses, de forma que o preço que pagarão pelas ações refletirá os custos de monitoramento e o efeito da divergência entre os interesses do administrador eos dos acionistas. Contudo, ignorando por enquanto a possibilidade de tomar empréstimos com a sua riqueza, o proprietário considerará desejável arcar com esses custos enquanto 0 incremento de bem-estar que ele ganhará convertendo seus direitos sobre a firma em poder de compra geral ${ }^{14}$ for grande o suficiente para compensá-los.

À medida quea parcela do capital próprio do proprietário-administrador diminui, os seus direitos parciais sobre o resultado também diminuem, o que o incentivará a se apropriar de maiores quantias dos recursos corporativos 
na forma de vantagens ou mordomias. Isso também fará com que seja desejável para os acionistas minoritários gastar mais recursos para monitorar o comportamento do administrador. Desta forma, os custos do proprietário, em termos de riqueza, para obter caixa adicional nos mercados de ações aumentam à medida que a sua propriedade parcial diminui.

Continuaremos a caracterizar o conflito de agência entre o proprietário-administrador e os acionistas externos como resultantes da tendência do administrador de se apropriar dos recursos da empresa, na forma de vantagens ou mordomias, para seu próprio consumo. Não pretendemos, contudo, deixar a impressão de que esta é a única, ou até mesmo a mais importante, fonte de conflitos. Com efeito, é provável que a maioria dos conflitos mais importantes sejam provenientes do fato de que, à medida que 0 direito pela propriedade do administrador diminui, o seu incentivo a dedicar um esforço significativo a atividades criativas como buscar novos empreendimentos lucrativos também diminui. Ele pode, na verdade, evitar esses empreendimentos simplesmente porque implicaria muita preocupação ou esforço de sua parte administrar ou aprender as novas tecnologias. A evasão desses custos pessoais e das ansiedades que os acompanham também representa, para ele, uma fonte de utilidade no trabalho, o que pode resultar no fato de o valor da firma ser substancialmente mais baixo do que seria de outra forma.

\section{Uma simples análise formal das fontes dos custos de agência do acionista externo e de quem arca com elas}

Para desenvolver uma estrutura para a análise a seguir, partimos de dois conjuntos de pressupostos. 0 primeiro conjunto (pressupostos permanentes) inclui aqueles que nos acompanharão praticamente ao longo toda a análise, das Seções de 2 a 5. Os efeitos da relativização de al guns desses pressu postos são discutidos na Seção 6 . 0 segundo conjunto (pressupostos temporários) éconstituído exclusi vamente para fins argumentativos e são rel ativizados assim que os pontos básicos tiverem sido esclarecidos.

\section{Pressupostos permanentes}

(P.1) Todos os impostos são zero.

(P.2) Não há crédito mercantil disponível.

(P.3) N enhuma ação de acionistas externos dá direito a voto.

(P.4) N enhum resgate financeiro complexo, como títulos conversíveis em ações, ações preferenciais ou títulos conversíveis, pode ser emitido.

(P.5) Nenhum proprietário externo recebe utilidade proveniente da propriedade de uma firma de qualquer maneira al ém de por meio de seu efeito sobre a sua riqueza ou fluxos de caixa.

(P.6) Todos os aspectos dinâmicos da natureza multiperíodo do problema são ignorados pela premissa de que há apenas uma decisão de produção-financiamento a ser tomada pelo empresário.

(P.7) Os salários monetários do empresário-administrador são mantidos constantes ao longo da análise.

(P.8) Há um único administrador (o principal coordenador) com interesse proprietário na empresa.

\section{Pressupostos temporários}

(T.1) 0 tamanho da firma éfixo.

(T.2) Nenhuma atividade de monitoramento ou de concessão de garantias contratuais é possível.

(T.3) N enhum financiamento do capital deterceiros por meio de obrigações, ações preferenciais ou empréstimos pessoais (garantidos ou não) é possível.

(T.4) Todos os elementos do problema de decisão do proprietário-administrador envolvendo considerações de portfólio induzi das pela presença da incerteza e pela existência de risco diversificável são ignorados.

\section{Definição}

$X=\left\{x_{1}, x_{2}, \ldots, x_{n}\right\}=$ vetor das quantidades de todos os fatores e atividades da firma das quais 0 administrador obtém benefícios não pecuniários; ${ }^{16} \mathrm{x}_{\mathrm{i}}$ são definidos de forma que a utilidade marginal do administrador seja positiva para cada um deles;

$C(X)=$ custo total em unidades monetárias para prover qual quer determinada quantidade desses itens;

$P(X)=$ val or total em unidades monetárias para a firma dos benefícios produtivos de $X$;

$B(X)=P(X)-C(X)=$ benefício líquido de $X$ para a empresa, em unidades monetárias, de ignorar quaisquer efeitos de $X$ sobre o salário de equilíbrio do administrador.

Ignorando os efeitos de $X$ sobre a utilidade do administrador e, conseqüentemente, o seu salário de equilíbrio, os níveis ótimos dos fatores e atividades $X$ são definidos por $X^{*}$, de forma que:

$$
\frac{\partial B\left(X^{*}\right)}{\partial X^{*}}-\frac{\partial P\left(X^{*}\right)}{\partial X^{*}}-\frac{\partial C\left(X^{*}\right)}{\partial X^{*}}=0 .
$$

Destaforma, para qual quer vetor $X \geq X *$ (i.e., no qual pelo menos um elemento de $X$ é maior do que seu elemento correspondente de $\left.X^{*}\right), F \equiv B\left(X^{*}\right)-B(X)>0$ mede 0 custo para a empresa, em unidades monetárias (líquido 
de quaisquer efeitos produtivos) de prover o incremento $X-X^{*}$ dos fatores e atividades que geram utilidade ao administrador. Supomos, deste ponto em diante, que, para qualquer determinado nível de custo para a firma, $F, o$ vetor dos fatores e atividades nos quais $F$ é gasto, $\hat{X}$, que rendem ao administrador a utilidade máxima. Desta forma, $\mathrm{F} \equiv \mathrm{B}\left(\mathrm{X}^{*}\right)-\mathrm{B}(\hat{X})$.

Até o momento ignoramos, na nossa discussão, o fato de que esses gastos em $X$ ocorrem ao longo do tempo e, desta forma, são trade-offs a serem decididos com o tempo eentre elementos alternativos deX. Além disso, ignoramos o fato de que os gastos futuros provavel mente envolverão incerteza (i.e., el es são sujeitos a distribuições de probabilidade) e, portanto, o risco deve ser, de al guma forma, deduzido. Solucionamos essas duas questões por meio da definição de C, P, B e F como os valores presentes de mercado da seqüência das distribuições de probabilidade no período de acordo com os fluxos de caixa envolvidos no período. ${ }^{17}$

Considerando a definição deF como o valor presente de mercado da série de gastos do administrador em benefícios não pecuniários, representamos, com a linha $\bar{V} F$ da Figura 1, a restrição de um único proprietário-administrador para decidir quanta renda não pecuniária el e extrairá da firma. Isso se assemel ha a uma restrição orçamentária. 0 valor de mercado da firma é mensurado ao longo do eixo vertical e o valor de mercado da série de gastos do administrador em ben efícios não pecuniários, $F$, é mensurado ao longo do eixo horizontal. $O \bar{V}$ éo val or da firma quando a quantia de renda não pecuniária consumida é zero. Por definição, $\bar{V}$ é o valor de mercado máximo dos fluxos de caixa gerados pela firma para um determinado salário do administrador quando o consumo de benefícios não pecuniários do administrador é zero. N este ponto, todos os fatores e atividades da firma que geram utilidade para 0 administrador estão no nível $X *$ definido acima. Há uma outra restrição orçamentária, $\bar{V} F$, para cada escala possível da firma (i.e., o nível de investimento, I) e para níveis al ternativos de salário, W, para 0 administrador. Por enquanto, escolhemos um nível arbitrário de investimento (que presumimos que já tenha sido feito) e mantemos constante a escala da firma nesse nível. Também presumimos que o salário do administrador seja fixo no nível $W^{*}$, que representa 0 valor presente de mercado de seu contrato salarial ${ }^{18}$ no pacote de remuneração ótimo que consiste tanto de salários, $W^{*}$, quanto de benefícios não pecuniários, $\mathrm{F}^{*}$. Pelo fato de o valor presente de um dólar de benefícios não pecuniários retirado da firma pelo administrador reduzir o valor de mercado da firma em $\$ 1$, por definição, a inclinação de $\bar{V} F$ é -1.
As preferências do proprietário-administrador por riqueza e benefícios não pecuniários são representadas na Figura 1 por um sistema de curvas de indiferença, $U_{1}, U_{2^{\prime}}$ etc. ${ }^{19} \mathrm{As}$ curvas de indiferença serão convexas enquanto a taxa marginal de substituição do proprietário-administrador entre benefícios não pecuniários e riqueza diminuir com os níveis crescentes dos benefícios. Para o proprietário integral-administrador da firma, isso pressupõe que não há substitu tos perfeitos para esses benefícios disponíveis externamente, i.e., em certa medida, eles são específicos à tarefa. Para o proprietário parcial-administrador, isso pressupõe que os benefícios não podem ser convertidos em poder de compra a um preço constante. ${ }^{20}$

Quando o proprietário detiver 100 por cento das ações, 0 valor da firma será $V *$ onde a curva de indiferença $U_{2}$ é tangente a VF e o nível de benefícios não pecuniários consumidos éF*. Se o proprietário vender todas as ações mas permanecer na firma como um administrador e se o comprador das ações puder, a custo zero, forçar o antigo proprietário (agora na qualidade de administrador) a receber o mesmo nível de benefícios não pecuniários do que quando era um proprietário, $V^{*}$ é o preço que 0 novo proprietário estará disposto a pagar pela totalidade das ações. ${ }^{21}$

Em geral, contudo, não esperaríamos que o novo proprietário fosse capaz de forçar um comportamento idêntico do antigo proprietário a custo zero. Se o antigo proprietário vender uma parte da firma a um investidor externo, ele, na qual idade de um administrador, não mais arcará com o custo total de quaisquer benefícios não pecuniários que consumir. Suponha que o proprietário venda uma participação da firma, $1-\alpha,(0<\alpha<1)$ e mantenha uma participação $\alpha$. Se o comprador potencial acreditar que o proprietário-administrador consumirá o mesmo nível de benefícios não pecuniários que consumia quando era o proprietário integral da firma, o comprador estará disposto a pagar $(1-\alpha) V^{*}$ por uma parcela $(1-\alpha)$ das ações. Considerando que um investidor externo agora detém os direitos a ( $1-\alpha$ ) das ações, contudo, o custo para o proprietário-administrador de consumir $\$ 1$ de benefícios não pecuniários da firma não será mais de $\$ 1$. Em vez disso, ele será de $\alpha \times \$ 1$. Se o comprador potencial de fato pagou $(1-\alpha) V^{*}$ pela sua participação do valor acionário e, se 0 administrador puder escolher o nível de benefícios não pecuniários que quiser, a sua restrição orçamentária será de $\mathrm{V}_{1} \mathrm{P}_{1}$, na Figura 1 , com uma inclinação igual a - $\alpha$. Incluindo o pagamento que o proprietário recebe do comprador como parte da riqueza pós-venda do proprietário, a sua restrição orçamentária, $\mathrm{V}_{1} \mathrm{P}_{1}$, deve passar por $D$, já que ele pode, se desejar, manter a mesma riqueza e 
nível de consumo não pecuniário que tinha quando era o proprietário integral da firma.

Mas, se o proprietário-administrador for livre para escolher o nível de vantagens ou mordomias, $F$, sujeito apenas à perda de riqu eza que incorrer como proprietário parcial, o seu bem-estar será maximizado pel o aumento de seu consumo de benefícios não pecuniários. Ele moverá para o ponto $A$, onde $V_{1} P_{1}$ é tangente $a U_{1}$, representando um nível mais al to de utilidade. $O$ valor da firma cai de $V^{*}$ a $V^{0}$, i.e., em função da quantia do custo à firma dos maiores gastos não pecuniários, o consumo de ben efícios não pecuniários por parte do proprietário-administrador aumenta de $\mathrm{F}^{*}$ a $\mathrm{F} 0$.

Se o mercado de ações for caracterizado por expectativas racionais, os compradores estarão cientes de que 0 proprietário aumentará o seu consumo não pecuniário quando a sua participação na firma for reduzida. Se a função de reação do proprietário for conhecida ou se 0 mercado de ações fizer estimativas imparciais da reação do proprietário às mudanças de incentivos, o comprador não pagará $(1-\alpha) V^{*}$ por $(1-\alpha)$ do capital próprio.

Teorema. Pelo direito sobre a firma, ( $1-\alpha)$, o investidor externo pagará apenas $(1-\alpha)$ vezes 0 valor que espera da empresa, considerando a mudança induzida do comportamento do proprietário-administrador.

Prova. Para fins de simplificação, ignoramos quaisquer el ementos de incerteza gerados pela falta de conhecimento perfeito da função de reação do proprietário-administrador. Essa incerteza não afetará a solução final se o mercado de ações for grande, contanto que as estimativas sejam racionais (i.e., imparciais) e os erros sejam independentes entre as firmas. A última condição garante que esse risco seja diversificável e, portanto, os preços no equilíbrio serão iguais aos valores esperados.

Consideramos queW representa a riqueza total do proprietário depois de vender um direito sobre a propriedade igual a 1 - $\alpha$ das ações a um investidor externo. W inclui dois componentes. Um deles é o pagamento, $\mathrm{S}_{0}$, feito pelo investidor externo por $1-\alpha$ do valor acionário; 0 restante, Si, é o valor da partici pação da firma retida pelo proprietário (i.e., investidor interno), de forma que W , a riqueza do proprietário, é dada por:

$$
W=S_{o}+S_{i}=S_{o}+\alpha V(F, \alpha)
$$

onde $V(F, \alpha)$ representa o valor da firma considerando

Figura 1 - 0 valor da firma (V) e o nível de benefícios não pecuniários consumidos (F) quando a parcela dos acionistas externos for $(1-\alpha) \vee$ e $U_{1}(j=1,2,3)$ representar as curvas de indiferença do proprietário entre a riqueza e os benefícios não pecuniários

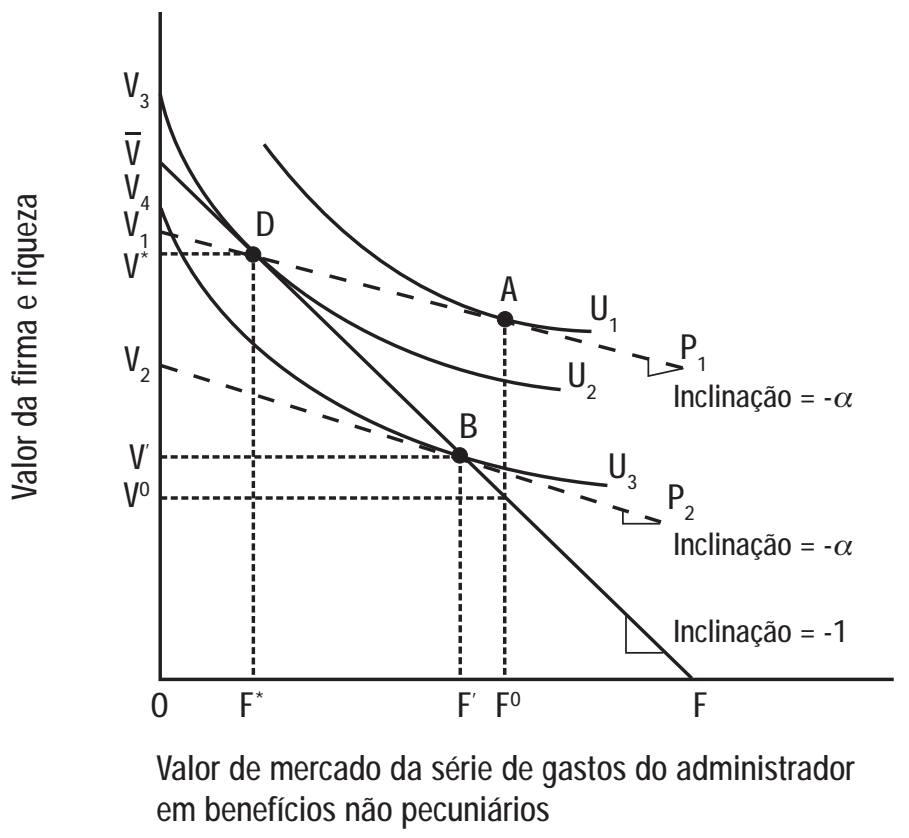


que a participação parcial do administrador seja $\alpha$ e que ele consuma vantagens e ações de propriedade de valor atual de mercado igual a $\mathrm{F} . \mathrm{V}_{2} \mathrm{P}_{2}$, com uma inclinação de $-\alpha$, representa o trade-off diante do proprietário-administrador entre os benefícios não pecuniários e a sua riqueza após a venda. Considerando que o proprietário decidiu vender os direitos sobre 1 - $\alpha$ da firma, o seu bem-estar será maximizado quando $\mathrm{V}_{2}-\mathrm{P}_{2}$ é tangente a uma curva de indiferença como a curva $U_{3}$, na Figura 1. Um preço pelos direitos sobre $(1-\alpha)$ da firma que seja satisfatório tanto para o comprador quanto para o vendedor demandará que essa tangência ocorra ao longo de $\bar{V} F$, i.e., que o valor da firma seja igual a $V^{\prime}$. Para demonstrar isso, suponha que este não seja o caso - que a tangência ocorra à esquerda do ponto $B$ na linha $\bar{V} F$. Desta forma, como a inclinação de $V_{2} P_{2}$ é negativa, o valor da firma será maior que V'. A escolha do proprietárioadministrador por esse nível mais baixo de consumo de benefícios não pecuniários implicará um valor mais al to tanto para a firma como um todo quanto para a parcela da firma ( $1-\alpha$ ) adquirida pelo investidor externo; isto é $(1-\alpha) V^{\prime}>$ So. Do ponto de vista do proprietário, ele vendeu 1 - $\alpha$ da firma por menos do que poderia ter recebido, considerando o nível mais baixo (presumido) de benefícios não pecuniários que recebe. Por outro lado, se a tangência do ponto $B$ for à direita da linha $\bar{V} F, 0$ consumo mais alto de benefícios não pecuniários por parte do proprietário-administrador significa que o valor da firma é menor que $V^{\prime}$ e que, portanto, $(1-\alpha) \mathrm{V}(\mathrm{F}$, $\alpha)<$ So $=(1-\alpha) V^{\prime}$. O proprietário externo, neste caso, pagou mais pela sua participação do capital próprio do que ela vale. So será um preço mutuamente satisfatório se, e somente se, $(1-\alpha) V^{\prime}=$ So. Mas isso significa que a riqueza pós-venda do proprietário é igual ao valor (reduzido) da firma, $V^{\prime}$, já que:

$$
W=S_{o}+\alpha V^{\prime}=(1-\alpha) V^{\prime}+\alpha V^{\prime}=V^{\prime} .
$$

Como queríamos demonstrar.

$O$ requisito de que $V$ ' e $F$ ' caiam sobre a linha $\bar{V} F$, desta forma, equivale a requerer que o valor do direito adquirido pelo comprador externo seja igual à quantia paga por ele ao proprietário. Isso significa que a diminuição do valor total da firma $\left(V^{*}-V^{\prime}\right)$ é imposta em sua totalidade sobre o proprietário-administrador. A sua riqueza total após a venda de $(1-\alpha)$ do valor acionário é de $V^{\prime}$, e a diminuição de sua riqueza é de $V^{*}-V^{\prime}$.

A distância $V^{*}$ - V'éa redução do valor de mercado da firma resultante da relação de agência e é uma medida da "perda residual" definida anteriormente. N este exemplo simplificado, o custo residual representa os custos totais de agência resultantes da venda do capital próprio externo pelo fato de as atividades de monitoramento ou concessão de garantias contratuais não serem permitidas. A perda de bem-estar incorrida pelo proprietário é menor que 0 custo residual do valor para ele resultante do aumento dos benefícios não pecuniários ( $\left.F^{\prime}-F^{*}\right)$. Na Figura 1 , a diferença entre as intersecções no eixo $Y$ das duas curvas de indiferença $U_{2}$ e $U_{3}$ é uma medida da perda de bemestar do proprietário-administrador devido à incidência de custos de agência, ${ }^{22}$ e ele venderia esse direito sobre a propriedade somente se 0 incremento de bem-estar obtido pela utilização do caixa equivalente a $(1-\alpha) \mathrm{V}^{\prime}$ em outros fins, for mais valorizado por ele do que a sua quantia de riqueza.

\section{Determinação da escala ótima da firma}

0 caso de financiamento somente com ações. Considere o problema diante de um empresário com riqueza pecuniária inicial $W$, e $o$ acesso do monopólio a um projeto que requeira um investimento I, sujeito a um retorno, decrescente em relação à escala, I. A Figura 2 demonstra a solução para a escala ótima da firma levando em consideração os custos de agência associados à existência de acionistas externos. Os eixos são os mesmos definidos na Figura 1 com a exceção de que, agora, plotamos no eixo vertical a riqueza total do proprietário, i.e., a sua riqueza inicial, W, mais V (I) - I, o incremento líquido de riqueza que ele obtém da exploração de suas oportunidades de investimento. $\mathrm{O}$ valor de mercado da firma, $\mathrm{V}=\mathrm{V}(\mathrm{I}, \mathrm{F})$, é, agora, uma função do nível de investimento, I, e do valor presente de mercado dos gastos de recursos da firma em benefícios não pecuniários para o administrador, F. $\bar{V}(I)$ representa o valor da firma como uma função do nível de investimento quando os gastos do administrador em benefícios não pecuniários, $F$, são zero. A linha com a intersecção identificada como $\left.\mathrm{W}+\left[\bar{V}\left(I^{*}\right)-\left.\right|^{*}\right)\right]$ e inclinação de -1 na Figura 2 representa o lugar geométrico das combinações da riqueza pós-investimento e do custo à firma, em unidades monetárias, de benefícios não pecuniários disponíveis ao administrador quando 0 investimento atinge o ponto maximizador de valor, I*. N este ponto, $\Delta \bar{V}(\mathrm{I})-\Delta \mathrm{l}=0$. Se a riqueza do administrador fosse grande o suficiente para cobrir o investimento necessário para atingir essa escala operacional, I*, ele consumiria $\mathrm{F}^{*}$ em benefícios não pecuniários e teria uma riqueza pecuniária de valor $\mathrm{W}+\mathrm{V}^{*}-I^{*}$. Contudo, se for necessário financiamento externo para cobrir 0 investimento, ele não atingirá esse ponto se os custos de monitoramento não forem zero. ${ }^{23}$ 
A trajetória da expansão OZBC representa as combinações de equilíbrio da riqueza e dos benefícios não pecuniários, $F$, que 0 administrador poderia obter se tivesse riqueza pessoal suficiente para financiar todos os níveis de investimento até I*. É - lugar geométrico de pontos como $Z$ e $C$ que representa a posição de equilíbrio para o proprietário integral-administrador em cada nível possível de investimento, I. À medida que I aumenta, subimos ao longo da trajetória de expansão até o ponto $C$, onde $V(I)$ - I atinge o máximo. Investimentos adicionais além desse ponto reduzem o valor líquido da firma e, à medida que isso acontece, a trajetória de equilíbrio da riqueza e dos benefícios não pecuniários do administrador reconstitui (na direção inversa) a curva OZBC. Esboçamos a traj etória como uma função côncava suave só por uma questão de praticidade.
Se 0 administrador obtivesse financiamento externo e se a relação de agência fosse de custo zero (talvez porque os custos de monitoramento sejam zero), a traj etória de expansão também seria representada por OZBC. Desta forma, essa trajetória representa o que poderíamos chamar de soluções "idealizadas", i.e., soluções que ocorreriam na ausência de custos de agência.

Suponha que 0 administrador tenha riqueza pessoal suficiente para financiar completamente a firma somente até 0 nível de investimento $I_{1}$, 0 que 0 leva até o ponto Z. Neste ponto, $W=I_{1}$. Para aumentar o tamanho da firma além desse ponto, ele deve obter financiamento externo para cobrir o investimento adicional necessário, 0 que significa reduzir a sua propriedade parcial. Quando isso é feito, ele incorre em custos de agência e, quanto menor for a sua parcela de propriedade, maiores são os custos de agência em que ele incorre. Contudo, se os in-

Figura 2 - Determinação da escala ótima da firma no caso em que não há monitoramento

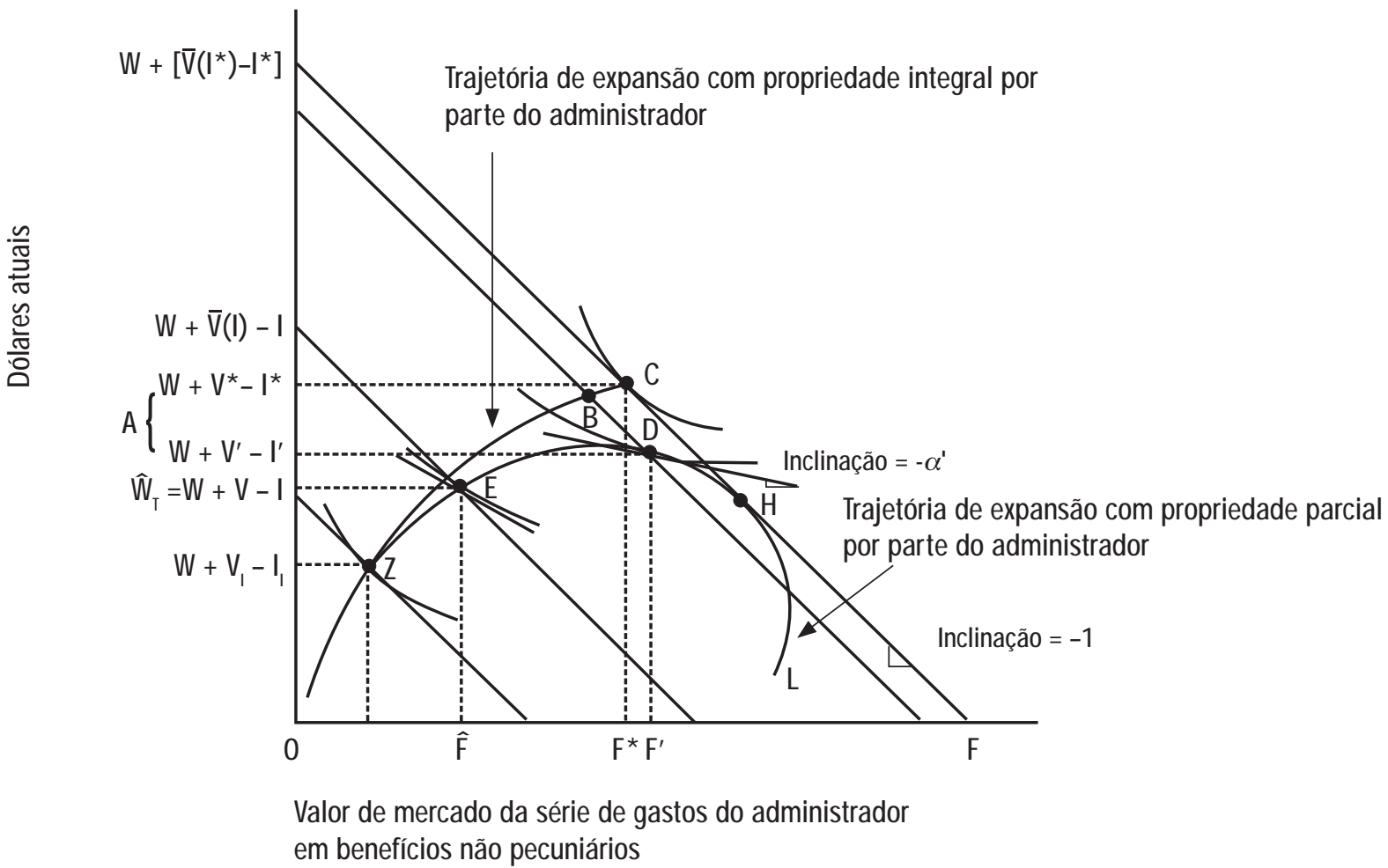

Nota: 0 ponto $\mathrm{C}$ indica o investimento ótimo, $I^{*}$, e os benefícios não pecuniários, F*, quando o investimento é $100 \%$ financiado pelo empresário. $O$ ponto $D$ indica o investimento ótimo, I', e benefícios não pecuniários, F, quando o financiamento de capital próprio externo é utilizado para financiar o investimento e o empresário retém uma parcela $\alpha^{\prime}$ da firma. A distância A mede os custos brutos de agência. 
vestimentos que requerem financiamento externo forem suficientemente lucrativos, o bem-estar do administrador continuará a aumentar.

A trajetória da expansão ZEDHL da Figura 2 representa uma trajetória possível dos níveis de equilíbrio da riqueza e dos benefícios não pecuniários do proprietário a cada nível possível de investimento maior que $I_{1}$. Essa trajetória é o lugar geométrico de pontos como $E$ ou $D$, onde (1) a curva de indiferença do administrador étangente a uma linha com inclinação igual $a-\alpha$ (os seus direitos parciais sobre a firma no nível do investimento) e (2) a tangência ocorre na "restrição orçamentária" com inclinação $=-1$ para o valor da firma e o trade-off do benefício não pecuniário no mesmo nível do investimento. ${ }^{24} \dot{A}$ medida que percorremos a curva ZEDHL os direitos parciais do administrador sobre a firma diminuem à medida que ele obtém maiores quantias de capital externo. Essa trajetória de expansão representa todo o conjunto de oportunidades do administrador para diferentes combinações de riqueza e benefícios não pecuniários na presença de custos da relação de agência com os investidores externos. $O$ ponto $D$, onde esse conjunto de oportunidades é tangente a uma curva de indiferença, representa a solução que maximiza o bem-estar do administrador. Neste ponto, o nível de investimento é I', a sua participação parcial da firma é $\alpha$ ', a sua riqueza é $W+V^{\prime}$ - I' e ele consome uma série de benefícios não pecuniários com valor atual de mercado de $\mathrm{F}^{\prime}$. Os custos brutos de agência (representados por $A$ ) são iguais a $\left(V^{*}-I^{*}\right)-\left(V^{\prime}-I^{\prime}\right)$. Considerando a impossibilidade de monitoramento, l'é o nível de investimento socialmente ótimo bem como o nível privado ótimo.

Podemos caracterizar o nível ótimo de investimento como o ponto I', que satisfaz à condição a seguir para pequenas variações:

$$
\Delta V-\Delta I+\alpha^{\prime} \Delta F=0 .
$$

$\Delta \mathrm{V}$ - $\Delta \mathrm{l}$ éa variação do valor de mercado líquido da firma e $\alpha^{\prime} \Delta \mathrm{F}$ é 0 val or em unidades monetárias para 0 administrador dos benefícios adicionais incrementais que ele consome (que custam à empresa $\Delta \mathrm{F}$ unidades monetárias) ${ }^{25}$ Além disso, reconhecendo que $V=\bar{V}-F$, onde $\bar{V}$ é o valor da firma em qual quer nível de investimento quando $\mathrm{F}=0$, substituímos na condição ótima para obter:

$$
(\Delta \bar{V}-\Delta I)-\left(1-\alpha^{\prime}\right) \Delta F=0
$$

como uma expressão alternativa para determinar o nível ótimo de investimento.
A solução de custo de agência ideal izada ou zero, I* , é dada pela condição $(\Delta \bar{V}-\mathrm{I})=0$ e, como $\Delta \mathrm{F}$ é positivo, o nível real de maximização do bem-estar do investimento I' será menor que ${ }^{*}$, porque $(\Delta \bar{V}-\Delta \mathrm{l})$ deve ser positivo em I' se a equação (3) deve ser satisfeita. Como - $\alpha$ ' é a inclinação da curva de indiferença no nível ótimo e, portanto, representa o preço de demanda do administrador por benefícios não pecuniários incrementais, $\Delta \mathrm{F}$, sabemos que $\alpha^{\prime} \Delta \mathrm{F}$ é o valor monetário para ele de um incremento de benefícios adicionais que custam à empresa AF unidades monetárias. 0 termo $\left(\mathrm{I}-\alpha^{\prime}\right) \Delta \mathrm{F}$, desta forma, mede a "perda" em unidades monetárias para a firma (e para o próprio administrador) de $\Delta \mathrm{F}$ unidades monetárias adicionais gastas em benefícios não pecuniários. 0 termo $\Delta \bar{V}-\Delta$ l é o incremento bruto relativo ao valor da firma ignorando quaisquer variações de consumo de benefícios não pecuniários. Desta forma, o administrador pára de aumentar o tamanho da firma quando o incremento bruto do val or é meramente compensado pela "perda" incremental incorrida pelo consumo de ben efícios adicionais devido a seu interesse parcial cada vez menor pela firma. ${ }^{26}$

\section{0 papel das atividades de monitoramento ou concessão de garantias contratuais na redução dos custos de agência}

$\mathrm{Na}$ análise acima, ignoramos o potencial de controle do comportamento do proprietário-administrador por meio de monitoramento e outras atividades de controle. $\mathrm{Na}$ prática, isso costuma ser possível gastando recursos para alterar a oportunidade que o proprietário-administrador tem de se favorecer de benefícios não pecuniários. Esses métodos incluem, entre outros, auditoria, sistemas formais de controle, restrições orçamentárias e o estabel ecimento de sistemas de incentivo e remuneração que servem para identificar com mais precisão os interesses do administrador e os dos investidores externos. A Figura 3 representa os efeitos do monitoramento e de outras atividades de controle na situação simples retratada na Figura 1. As Figuras 1 e 3 são idênticas, exceto pela curva BCE da Figura 3, que representa uma "restrição orçamentária" formada quando as possibilidades de monitoramento são levadas em consideração. Sem monitoramento e com um capital próprio externo de $(1-\alpha)$, o val or da firma será V' e os gastos não pecuniários serão $F^{\prime}$. Ao incorrer em custos de monitoramento, $M$, os detentores do capital próprio podem restringir o consumo de vantagens ou mordomias do administrador a quantias abaixo de $F^{\prime} . F(M, \alpha)$ representa o nível máximo de vantagens ou mordomias que o administrador pode consumir para níveis alternativos de despesas de monitoramento, $M$, considerando que a 
sua participação é de $\alpha$. Presumimos que incrementos do monitoramento reduzam $\mathrm{F}$ e que isso ocorra em uma taxa decrescente, i.e., $\partial \mathrm{F} / \partial \mathrm{M}<0$ e $\partial^{2} \mathrm{~F} / \partial \mathrm{M}^{2}>0$.

Como o valor atual das despesas esperadas futuras de monitoramento por parte dos investidores externos reduzem o val or de qualquer determinado direito que eles possam ter sobre a firma em cada unidade monetária investida, os acionistas levarão isso em consideração na definição do preço máximo que pagarão por qualquer determinada parcela de capital próprio da firma. Portanto, considerando uma atividade de monitoramento positiva, o valor da firma édado por $V=\bar{V}-F(M, \alpha)$ - M eo lugar geométrico desses pontos para vários níveis $M$ e para um determinado nível de $\alpha$ se situa na curva BCE da Figura 3. A diferença vertical entre as curvas $\bar{V} F$ eBCE éM, o valor atual de mercado das despesas futuras de monitoramento.

Se for possível para os acionistas externos promover essas despesas de monitoramento e, desta forma, impor restrições do consumo, F, por parte do proprietário-administrador, este voluntariamente firmará um contrato com os acionistas externos Ihes concedendo os direitos de restringir o seu consumo de itens não pecuniários a
$F^{\prime \prime}$. Ele considerará isso desejável porque isso fará com que o valor da firma aumente para V". Considerando 0 contrato, as despesas de monitoramento por parte dos investidores externos, $M$, são da ordem de $D$ - C. Todo o aumento de valor da firma resultante se refletirá na riqueza do proprietário, mas o seu bem-estar terá incrementos menores do que isso por ser forçado a abdicar de al guns ben efícios não pecuniários dos quais se beneficiava anteriormente.

Se o mercado de ações for competitivo e fizer estimativas imparciais dos efeitos das despesas de monitoramento sobre F eV, os compradores potenciais serão indiferentes entre os dois contratos a seguir:

(i) Compra de uma participação ( 1 - $\alpha$ ) da firma ao preço total de $(1-\alpha) V^{\prime}$ ' e nenhum direito de monitorar ou controlar o consumo de mordomias por parte do administrador.

(ii) Compra de uma participação $(1-\alpha)$ da firma ao preço total de $(1-\alpha) V^{\prime \prime}$ e o direito de gastar recursos até uma quantia igual $D-C, 0$ que limitará 0 consumo de mordomias por parte do proprietárioadministrador a F ;.

Figura 3 - 0 valor da firma (V) e o nível de benefícios não pecuniários (F) quando os acionistas externos possuem fração (1 - $\alpha$ ) das ações, $U_{1}, U_{2}, U_{3}$ representam as curvas de indiferença entre a riqueza e os benefícios não pecuniários, e as atividades de monitoramento (ou de concessão de garantias contratuais) impõem o conjunto de oportunidade BCE como a restrição do trade-off diante do proprietário

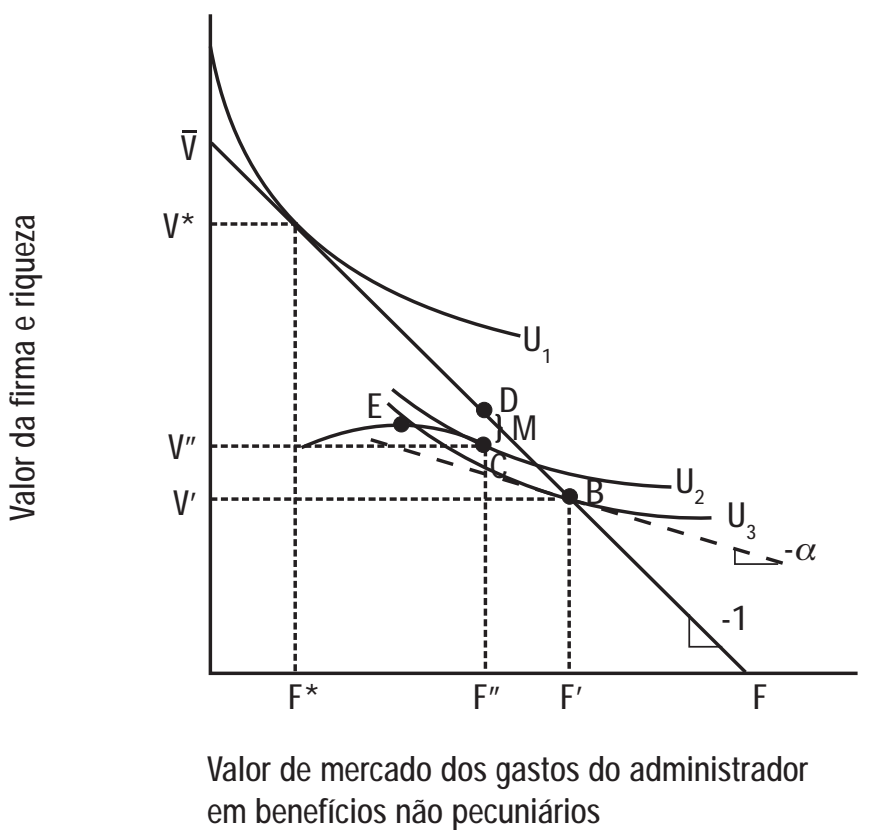


Com o contrato (ii) os acionistas externos considerariam desejável exercer todos os direitos de monitoramento permitidos por perceberem recompensas nisso. Contudo, se o mercado de ações for competitivo, os benefícios totais (líquido dos custos de monitoramento) serão capitalizados no preço das ações. Desta forma, não é de se surpreender que o proprietário-administrador colha todos os benefícios da oportunidade para elaborar e vender o contrato de monitoramento. ${ }^{27}$

U ma análise das despesas com a concessão de garantias contratuais. Anal isando a Figura 3, também podemos notar que não faz diferença quem de fato incorrenas despesas de monitoramento - o proprietário arca com a total idade desses custos na forma de uma redução da riqueza em todos os casos. Suponha que o proprietário-administrador possa gastar recursos, que custam $\mathrm{F}$ à empresa, para garantir aos acionistas externos que ele limitará suas atividades. Chamaremos esses gastos de "custos de concessão de garantias contratuais" e el es podem assumir diferentes formas, como garantias contratuais para que os registros financeiros sejam auditados por um contador externo, contratos explícitos contra infrações por parte do administrador e limitações contratuais ao poder de decisão do administrador (que impõem custos sobre a firma por limitarem a capacidade do administrador de se ben eficiar ao máximo de al gumas oportunidades lucrativas além de limitar a sua capacidade de prejudicar os acionistas em benefício próprio).

Se a incidência dos custos de concessão de garantias contratuais estivesse completamente sob o controle do administrador e se eles gerassem o mesmo conjunto de oportunidade BCE para 0 administrador que 0 representado na Figura 3, ele arcaria com os custos na quantia $D$ - C. Isso limitaria o seu consumo de vantagens ou mordomias de F' a F", e a solução é exatamente a mesma do que se os acionistas externos conduzirem o monitoramento. 0 administrador considera interessante incorrer nesses custos se os incrementos líquidos de sua riqueza gerados com isso (por meio da redução dos custos de agência e, conseqüentemente, do aumento do valor da firma) valerem mais do que as mordomias de que ele abdica. Esse ponto ótimo ocorre no ponto $\mathrm{C}$ em ambos os casos pela nossa premissa de que as despesas com a concessão de garantias contratuais resultam do mesmo conjunto de oportunidade que as despesas de monitoramento. Em geral, é claro, compensará ao proprietário-administrador envolver-se em atividades de concessão de garantias contratuais e elaborar contratos que permitam o monitoramento se os benefícios marginais de cada um excederem o seu custo marginal.
Escala ótima da firma na presença de atividades de monitoramento e de concessão de garantias contratuais. Se permitirmos que os proprietários externos se envolvam em atividades (custosas) de monitoramento para limitar os gastos do administrador em benefícios não pecuniários e permitirmos que o administrador se envolva em atividades de concessão de garantias contratuais para assegurar aos proprietários que ele limitará o seu consumo a $\mathrm{F}$, isso resultará em uma trajetória de expansão como a ilustrada na Figura 4, passando pelos pontos Z e G. Supomos, ao traçar a Figura 4, que as funções de custo envolvidas no monitoramento e na concessão de garantias contratuais são tais que al guns níveis positivos das atividades são desejáveis, i.e., geram benefícios superiores ao seu custo. Se isso não for verdadeiro, a trajetória de expansão gerada pelo dispêndio de recursos nessas atividades ficaria abaixo de ZD e uma atividade como essa não ocorreria em nenhum nível de investimento. Os pontos $Z, C$ eD eas duas traj etórias de expansão que passam por eles são idênticos aos representados na Figura 2 . Os pontos $Z$ e $C$ estão na trajetória de expansão da propriedade integral e os pontos Z e D estão na trajetória de expansão da propriedade parcial sem nenhuma atividade (zero) de monitoramento e de concessão de garantias contratuais.

A trajetória que passa pelos pontos Z e G é curva dada pelo lugar geométrico dos pontos de equilíbrio para níveis alternativos de investimento caracterizados pelo ponto C da Figura 3, que representa o nível ótimo de atividade de monitoramento e de concessão de garantias contratuais e os valores resultantes da firma e dos benefícios não pecuniários ao administrador em um dado nível fixo de investimento. Se qual quer monitoramento ou concessão de garantias contratuais for eficaz em termos custo, a trajetória de expansão que passa pelos pontos Z e G deveficar acima da trajetória de expansão de não monitoramento em al guma extensão. Além disso, se a curva se localizar em qualquer ponto à direita da curva de indiferença que passa pelo ponto $D$ (a solução de zero monitoramentoconcessão de garantias contratuais), a solução final para o problema envolverá quantias positivas de atividades de monitoramento e/ou concessão de garantias contratuais. Com base na discussão acima, sabemos que, se os contratos entre 0 administrador e os acionistas externos forem claros em relação aos direitos das respectivas partes, a solução final se localizará em um ponto no qual a nova trajetória de expansão é apenas tangente ao ponto mais al to da curva de indiferença. $N$ este ponto, os níveis ótimos das despesas de monitoramento e com a concessão de garantias contratuais são $\mathrm{M}$ " e b", a riqueza do administrador após o investimento e o financiamento é dada por W + 
V" - I" - M" - b" e os seus benefícios não pecuniários são $F^{\prime \prime}$. Os custos brutos de agência, $A$, são dados por $A$ ( $M$ ", $\left.b^{\prime \prime}, \alpha^{\prime \prime}, I^{\prime \prime}\right)=\left(V^{*}-I^{*}\right)-\left(V^{\prime \prime}-I^{\prime \prime}-M^{\prime \prime}-b^{\prime \prime}\right)$.

\section{Ótimo de Pareto e custos de agência em empresas operadas por um administrador}

Em geral esperamos observar tanto atividades de concessão de garantias contratuais quanto de monitoramento externo, e os incentivos são tais que os níveis dessas atividades satisfarão às condições de eficiência. Contudo, eles não resultarão na operação da empresa de forma a maximizar o seu valor. A diferença entre $V *$, a solução eficiente com custo zero de monitoramento e de concessão de garantias contratuais (e, desta forma, custo zero de agência), e V", o valor da firma com custos positivos de monitoramento, são os custos brutos de agência definidos na Introdu ção. Esses são os custos da "separação entre posse e controle", aos quais Adam Smith se referiu no trecho citado no início deste artigo e que Berlee M eans
(1932) popularizaram 157 anos mais tarde. As soluções esboçadas acima para o nosso problema al tamente simplificado implicam que os custos de agência serão positivos enquanto os custos de monitoramento forem positivos o que certamente é o caso.

0 valor reduzido da firma resultante do consumo de vantagens ou mordomias por parte do administrador, conforme descrito acima, é "não ótimo" ou ineficiente apenas em comparação com um mundo no qual seria possível obter a conformidade do agente aos desejos do principal (de uma dívida) a custo zero ou em comparação com um mundo hipotético no qual os custos de agência são mais baixos. Mas esses custos (custos de monitoramento e de concessão de garantias contratuais e "perda residual") são um resultado inevitável da relação de agência. Além disso, como são gerados totalmente pelo tomador de decisões (neste caso, o proprietário original) responsável pela criação da relação, 0 administrador tem incentivos para minimizá-los (já que ele se favorece dos

Figura 4 - Determinação da escala ótima da firma para permitir atividades de monitoramento e de concessão de garantias contratuais

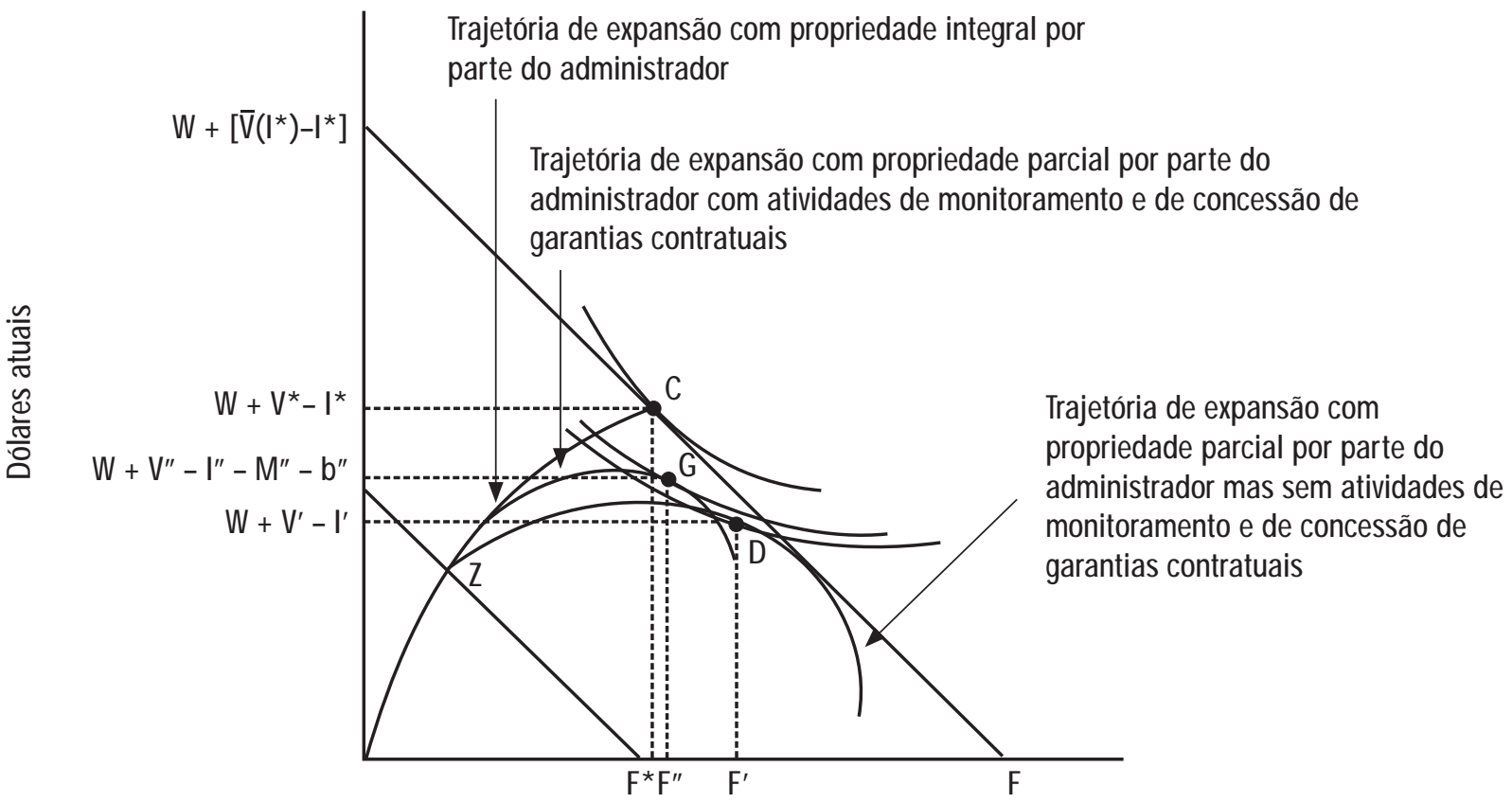

Valor de mercado da série de gastos do administrador em benefícios não pecuniários

Nota: Os custos de monitoramento ótimos são representados por M", os custos de concessão de garantias contratuais ótimos são representados por b", e a escala de equilíbrio da firma, a riqueza e o consumo de benefícios não pecuniários por parte do administrador estão no ponto G. 
benefícios de sua redução). E esses custos de agência serão incorridos somente se os benefícios de sua criação ao proprietário-administrador forem suficientes para excedêlos. No nosso exemplo atual, esses ben efícios surgem da disponibilidade de investimentos lucrativos que requerem investimento de capital acima da riqueza pessoal do proprietário original.

Em conclusão, descobrir que os custos de agência não são zero (i.e., que são custos associados com a separação entre posse e controle na empresa) e concluir, a partir daí, que a relação de agência é não ótima, ou é dispendiosa ou ineficiente equivale em todos os sentidos a comparar um mundo no qual o minério de ferro é uma commodity escassa (e, portanto, custosa) com um mundo no qual ele é disponível de graça a custo zero e concluir que 0 primeiro mundo é "não ótimo" - um perfeito exemplo da falácia criticada por Coase (1964) e caracterizada por Demsetz (1969) como uma modalidade de análise no "Nirvana". 28

\section{Fatores que afetam a extensão da divergência da maximização ideal}

A magnitude dos custos de agência discutidos acima variará de uma firma a outra. Ela dependerá das preferências dos administradores, da facilidade na qual el es conseguem exercitar suas próprias preferências em oposição à maximização de valor na tomada de decisões e dos custos das atividades de monitoramento e de concessão de garantias contratuais. ${ }^{28}$ Os custos de agência também dependerão do custo de mensurar e avaliar o desempenho do administrador (agente), o custo de elaborar e implementar um índice para definir a remuneração do administrador que se correlacione com o bem-estar do proprietário (principal) e o custo de elaborar e aplicar regras ou políticas comportamentais específicas. N os casos em que 0 administrador não detém a participação majoritária da firma, ela também dependerá do mercado de administradores. A concorrência de outros administradores potenciais limita os custos de obtenção dos serviços de administração (incluindo a extensão na qual um dado administrador pode divergir da solução idealizada que obteria se todos os custos de monitoramento e de concessão de garantias contratuais fossem zero). A extensão da divergência (os custos de agência) será diretamente relacionada com o custo de substituir 0 administrador. Se as responsabilidades do administrador demandarem pouco conhecimento especializado para a firma, seráfácil avaliar o seu desempenho e, se os custos de busca de uma substituição forem modestos, a divergência do ideal será relativamente pequena, e vice-versa.

A divergência também serálimitada pelo mercado para a própria firma, i.e., pelos mercados de capital. Os proprietários sempre têm a opção de vender a firma, seja no total ou em partes. Os proprietários de firmas operadas por um administrador podem examinar o mercado de capital de tempos em tempos, e de fato o fazem. Se descobrirem que o valor dos rendimentos futuros das outras é superior ao valor da firma deles, supondo que ambas sejam operadas por administradores, eles podem exercitar seu direito de vender. Seria plausível pensar que outros proprietários podem ser mais eficientes no monitoramento ou até mesmo que um indivíduo com talentos administrativos apropriad os e com uma riqueza pessoal suficiente grande escolheria comprar a firma. N este caso, a compra por esse indivíduo eliminaria completamente os custos de agência. Se houver vários compradores proprietáriosadministradores potenciais (todos com talentos e preferências idênticos ao administrador atual), os proprietários receberiam no preço de venda da firma o valor integral dos direitos residuais, incluindo o valor do capital dos custos de agência eliminados mais o valor dos direitos administrativos.

\section{Monopólio, concorrência e comportamento dos} administradores

Costuma-se argumentar que a presença da concorrência nos mercados de produtos (e fatores) restringirá o comportamento dos administradores à maximização ideal izada de valor, i.e, que o monopólio em mercados de produtos (ou o monopsônio no caso de fatores) permitirá maiores divergências em relação à maximização do valor ${ }^{30} \mathrm{~A}$ nossa análise não sustenta essa hipótese. Os proprietários de uma firma com poder de monopólio têm os mesmos incentivos a limitar as divergências do administrador em relação à maximização de valor (i.e., a capacidade de aumentar sua riqueza) que os proprietários de firmas competitivas. Além disso, a concorrência no mercado de administradores em geral tornará desnecessário para os proprietários compartilhar as rendas com o administrador. Os proprietários de uma firma de um monopólio só precisam pagar o preço de oferta por um administrador.

Como o proprietário de um monopólio tem os mesmos incentivos de riqueza para minimizar os custos administrativos que o proprietário de uma firma competitiva, ambos aplicarão o nível de monitoramento equivalente ao custo marginal de monitoramento ao incremento marginal da riqueza resultante do consumo reduzido de vantagens ou mordomias por parte do administrador. Desta forma, a existência de um monopólio não aumentará os custos de agência.

Além disso, a existência da concorrência em mercados 
de produtos e fatores não eliminará os custos de agência devido a problemas de controle administrativo, como já foi repetidamente exposto [cf. Friedman (1970)]. Se todos os meus concorrentes incorrerem em custos de agência iguais ou superiores aos meus, eu não serei eliminado do mercado pela concorrência.

A existência e o volume dos custos de agência dependem da natureza dos custos de monitoramento, das preferências dos administradores por benefícios não pecuniários e da oferta de administradores potenciais capazes de financiar todo o empreendimento com a sua riqueza pessoal. Se os custos de monitoramento forem zero, os custos de agência serão zero ou, se houver proprietários integrais-administradores suficientes disponíveis para controlar total mente e operar todas as firmas de um setor (competitivo ou não), os custos de agência desse setor também serão zero. ${ }^{31}$

\section{ALGUMAS QUESTÕES NÃO RESPONDIDAS REFERENTES À EXISTÊNCIA DA FORMA CORPORATIVA}

\section{A questão}

A análise até este ponto nos deixa com uma dúvida básica: por que, dada a existência de custos positivos da relação de agência, descobrimos que a forma corporativa normal da organização com posse amplamente pulverizada é tão amplamente predominante? Seformos levar a sério grande parte da literatura referente ao poder "discricionário" detido pelos administradores de grandes empresas, fica difícil compreender o fato histórico do enorme crescimento de acionistas externos nessas organizações, não apenas nos Estados Unidos, mas no mundo inteiro. Parafraseando Alchian (1968): Por que milhões de indivíduos estão dispostos a entregar uma parcel a significativa de sua riqueza a organizações operadas por administradores que têm tão pouco interesse no bem-estar desses indivíduos? E, ainda mais notável, por que eles estão dispostos a se envolver meramente como requerentes residuais, i.e., com base na premissa de que esses administradores operarão a firma de forma que os acionistas recebam rendimentos?

Certamente não há fal ta de formas alternativas de investimento para esses indivíduos, incluindo formas completamente diferentes de organizações. Mesmo se essas considerações se limitarem a organizações corporativas, há, claramente, formas al ternativas de levantar capital, i.e., por meio de obrigações de várias naturezas, títulos, notas, hipotecas etc. Além disso, o imposto de renda corporativo parece favorecer a utilização de dívida, já que os juros são tratados como uma despesa que pode ser deduzida dos impostos. Os que afirmam que os administradores não se comportam de acordo com os interesses dos acionistas em geral não abordaram uma questão de grande importância: se as ações não detidas por administradores apresentam uma deficiência tão séria, por que el as já não foram substituídas por dívida há muito tempo? ${ }^{32}$

\section{Algumas explicações alternativas da estrutura de propriedade da firma}

0 papel da responsabilidade limitada. Manne (1967) e Alchian e Demsetz (1972) argumentam que uma das características atraentes da forma corporativa vis-à-vis sociedades ou firmas de propriedade individual éa característica de responsabilidade limitada dos direitos sobre o capital próprio nas empresas. Sem essa característica, cada um dos investidores que comprarem uma ou mais ações de uma empresa teriam toda a extensão de sua riqueza pessoal potencialmente suscetível para cobrir as dívidas da empresa. Poucas pessoas aceitariam correr esse risco e os principais benefícios a ser obtidos com a redução dos riscos por meio da diversificação seriam, em grande extensão, inal cançáveis. Esse argumento, contudo, é incompleto, já que a responsabilidade limitada não elimina o risco básico, mas meramente o desloca. 0 argumento deve, em última instância, se basear nos custos de transações. Se todos os acionistas da GM forem responsáveis pelas dívidas da $\mathrm{GM}$, a máxima responsabilidade para um acionista individual seria maior do que se suas ações tivessem uma responsabilidade limitada. Contudo, considerando a existência de muitos outros acionistas e que cada um é responsável pelos resgates não pagos na proporção de sua participação, é al tamente improvável que o pagamento máximo que cada um deveria fazer fosse grande no caso de a GM abrir falência, já que a riqueza total desses acionistas também seria grande. Contudo, a existência de responsabilidade ilimitada imporia incentivos para cada acionista para monitorar tanto as responsabilidades da GM quanto a riqueza dos outros proprietários da GM. É plausível pensar que os custos dessa ação seriam, no total, muito maiores do que o mero pagamento de um prêmio na forma de taxas de juros superiores aos credores da GM em troca de sua aceitação de um contrato que garantisse responsabilidade limitada aos acionistas. Os credores, então, arcariam com o risco de qualquer inadimplência de dívidas no caso da falência da GM.

Também não é em geral reconhecido que a responsabilidade limitada é meramente uma condição necessária para explicar a extensão da confiança nas ações, não uma 
condição suficiente. Obrigações ordinárias também se caracterizam pela responsabilidade limitada. ${ }^{33}$ Se não for necessário nada além da responsabilidade limitada, por que não observamos grandes empresas, de propriedade individual, com uma pequena parcela do capital fornecida pelo empresário e o resto simplesmente tomado de empréstimo $?^{34}$ À primeira vista essa pergunta pode soar tola para muitas pessoas (como a pergunta relativa a por que as firmas emitiriam obrigações ou ações preferenciais em condições nas quis não há benefícios de impostos obtidos do tratamento dos juros ou de pagamentos de dividendos preferenciais ${ }^{35}$ ). Descobrimos que, em muitas ocasiões, essa questão é mal compreendida como uma pergunta sobre por que as firmas obtêm capital. A questão não é por que elas obtêm capital, mas por que elas o obtêm por meio das formas específicas que observamos por períodos tão longos? 0 fato éque não existe nenhuma resposta bem articulada a essa pergunta na literatura tanto da ciência econômica quanto financeira.

A "irrelevância" da estrutura de capital. Em seu artigo pioneiro sobre o custo do capital, Modigliani e Miller (1958) demonstraram que, na ausência de custos de falência e subsídios fiscais sobre o pagamento de juros, 0 valor da firma independe da estrutura financeira. Mais tarde (1963) el es demonstraram que a existência de subsídios fiscais para os pagamentos de juros faria com que o valor da firma aumentasse com a quantia de financiamento de dívida na quantia do valor capitalizado do subsídio fiscal. Essa linha de argumentação, contudo, implica que a firma deveria ser financiada quase total mente com capital de terceiros. Percebendo a inconsistência com 0 comportamento observado, Modigliani e Miller (1963, p. 442) comentam:

“Pode ser útil lembrar mais uma vez os leitores que a existência de uma vantagem fiscal para o financiamento de capital de terceiros... não significa necessariamente que as empresas deveriam utilizar, o tempo todo, a quantia máxima de capital de terceiros nas suas estruturas de capital. ... como salientamos, há limitações impostas pelos credores... bem como muitas outras dimensões (e tipos de custos) dos problemas de estratégia financeira no mundo real, que não são plenamente compreendidas no contexto dos modelos de equilíbrio estático, seja o nosso ou os mais tradicionais. Essas considerações adicionais, normal mente agru padas sob a rubrica da 'necessidade de preservar a flexibilidade', normalmente implicarão a manutenção, pela empresa, de reservas substanciais de poder inexplorado de tomada de empréstimos".

Modigliani e Miller são, essencialmente, deixados em uma teoria da determinação da estrutura de capital óti- ma e Fama e Miller (1972, p. 173), comentando sobre a mesma questão, reiteram essa conclusão:

“E devemos admitir que, neste ponto, há poucas pesquisas convincentes, independentemente de serem teóricas ou empíricas, para explicar as quantias de capital de terceiros que as firmas decidem incorporar em sua estrutura de capital".

0 teorema de Modigliani-Miller se baseia na premissa de que a distribuição de probabilidade dos fluxos de caixa para a empresa independe da estrutura de capital. Hoje se reconhece que a existência de custos positivos associados à falência e a presença de subsídios fiscais para os pagamentos de juros corporativos invalidará esse teorema da irrelevância justamente porque a distribuição de probabilidade dos fluxos de caixa futuros muda à medida que a probabilidade da incidência dos custos de falência muda, i.e., à medida que a razão entre capital de terceiros e capital próprio aumenta. Acreditamos que a existência de custos de agência fornece razões mais sólidas para argumentar que a distribuição de probabilidade de fluxos de caixa futuros não é independente da estrutura de propriedade ou de capital.

Apesar de a inclusão de custos de falência na presença de subsídios fiscais leva a uma teoria que defina uma estrutura de capital ótima, ${ }^{36}$ argumentamos que essa teoria é gravemente incompleta, já que implica que nenhum capital de terceiro jamais deveria ser utilizado na ausência de subsídios fiscais se os custos de falência forem positivos. Como sabemos que o capital de terceiros já era comumente utilizado antes da existência dos subsídios fiscais atuais para os pagamentos de juros, essa teoria não inclui o que seriam importantes determinantes da estrutura de capital corporativa.

Além disso, nem os custos de fal ência nem a existência de subsídios fiscais podem explicar a utilização de ação preferencial ou títulos conversíveis sem nenhuma vantagem fiscal e não há nenhuma teoria que nos informe al go sobre o que determina a parcela dos direitos sobre o capital próprio detido por insiders em oposição a outsiders, que a nossa análise apresentada na Seção 2 sugere ser tão importante. Retornaremos a essas questões mais adiante, após analisar em detalhes os fatores que afetam os custos de agência associados ao capital de terceiros.

\section{OS CUSTOS DE AGÊNCIA DO CAPITAL DE TERCEIROS}

Em geral, se os custos de agência resultantes da existência de proprietários externos forem positivos, compensará ao proprietário ausente (i.e., os acionistas) vender 
as ações a um proprietário-administrador que possa evitar esses custos. ${ }^{37}$ Isso poderia ser concretizado, em princípio, fazendo com que o administrador se torne 0 único detentor do capital próprio por meio da recompra de todos os direitos sobre dos acionistas externos com fundos obtidos por meio da emissão de dívidas de responsabilidade limitada e a utilização de sua própria riqueza pessoal. Essa empresa de um único proprietário não sofreria com os custos de agência associados aos acionistas externos. Desta forma, deve haver razões convincentes para explicar por que encontramos tão grande preponderância da forma organizacional caracterizada por firmas corporativas de posse pulverizada financiadas por capital próprio.

Um empresário inteligente, ansioso pela expansão, tem a possibilidade de projetar toda uma hierarquia de obrigações fixas sobre ativos elucros, com prêmios pagos para diferentes níveis de risco. ${ }^{38}$ Por que não observamos grandes empresas de propriedade individual com uma pequena parcela do capital fornecida pelo empresário em forma de 100 por cento do capital próprio, e o resto simplesmente tomado de empréstimo? Acreditamos que isso ocorre por uma série de razões: (1) os efeitos sobre o incentivo associados a firmas altamente alavancadas, (2) os custos de monitoramento que esses efeitos sobre o incentivo implicam e (3) os custos e falência. Além disso, todos esses custos são meramente aspectos específicos dos custos de agência associados à existência de direitos sobre o capital de terceiros na firma.

\section{Os efeitos sobre 0 incentivo associados ao capital de terceiros}

Não encontramos muitas grandes firmas financiadas quase intei ramente com capital detercei ros (i.e., direitos não residuais) em virtude do efeito que uma estrutura financeira como essa teria sobre o comportamento do proprietárioadministrador. Credores potenciais não concederão um empréstimo de $\$ 100.000 .000$ a uma to firma na qual o a empresário tem um investimento de $\$ 10.000$. Com essa estrutura financeira, o proprietário-administrador terá um grande incentivo a se envolver em atividades (investimentos) que prometam compensações pessoais muito altas se forem bem-sucedidas, mesmo se apresentarem uma probabilidade muito baixa de sucesso. Se as atividades tiverem sucesso, ele se favorece da maior parte dos ganhos, mas, se não tiverem sucesso, os credores arcam com a maior parte dos custos. ${ }^{39}$

Para ilustrar os efeitos sobre o incentivo associados à existência de capital de terceiros e para proporcionar um quadro conceitual no qual podemos discutir os efeitos dos custos de monitoramento e de concessão de garantias contratuais, transferências de riqueza e a incidência de custos de agência, consideraremos, mais uma vez, uma situação simples. Suponha uma empresa de propriedade de um administrador sem dívidas em aberto em um mundo onde não existem impostos. A firma tem a oportunidade de optar por uma das duas oportunidades de investimento de mesmo custo e mutuamente exclusivas, cada uma das quais resulta em um resultado (payoff) aleatório, $\tilde{X}_{j^{\prime}}$ T período no futuro $(j=1,2)$. Atividades de produção e monitoramento são realizadas continuamente entre 0 tempo 0 e o tempo $T$, e os mercados nos quais os direitos sobre a empresa podem ser negociados se mantêm continuamente abertos ao longo desse período. A pós o tempo $T$ a firma não tem mais atividades produtivas, de forma que o resultado $\tilde{X}_{j}$ inclui a distribuição de todos os ativos restantes. Para fins de simplificação, presumimos que as duas distribuições apresentam distribuição log normal e o mesmo lucro total esperado, $\mathrm{E}\left(\tilde{X}_{j}\right)$, onde $\tilde{X}_{j}$ é definido como o logaritmo do lucro final. As distribuições só diferem em suas variâncias, com $\sigma_{1}^{2}<\sigma_{2}^{2}$. Os riscos sistemáticos ou de covariância de cada uma das distribuições, $\beta_{\mathrm{i}}$, no modelo de precificação de ativos de capital de Sharpe (1964) - Lintner (1965), são supostamente idênticos. Presumindo que os preços dos ativos sejam determinados de acordo com o model o de precificação de ativos de capital, as premissas anteriores sugerem que 0 valor de mercado total de cada uma dessas distribuições é idêntico e representamos esse valor por $V$.

Se o proprietário-administrador tiver o direito de decidir qual programa de investimento escolher e, se, após a sua decisão el e tiver a oportunidade de vender parte ou todos os seus direitos sobre os resultados na forma de capital de terceiros ou de ações, ele se manterá indiferente entre os dois investimentos. ${ }^{40}$

Contudo, se o proprietário tiver a oportunidade de primeiro emitir a dívida e depois decidir quais investimentos fazer e depois vender todos ou parte de suas ações no mercado, ele não se manterá indiferente entre os dois investimentos. A razão para isso é que, ao prometer optar pelo projeto de baixa variância, vender obrigações e depois optar pelo projeto de alta variância, ele pode transferir riqueza dos detentores (ingênuos) das obrigações para si na qualidade de um detentor do capital próprio.

$X^{*}$ é a quantia dos direitos "fixos" na forma de uma obrigação sem cupom vendida aos detentores das obrigações de forma que o lucro total para eles, $R_{j}(j=1$, 2 , representa a distribuição escolhida pelo administrador), é: 


$$
\begin{array}{lll}
R j=\mathrm{X}^{*}, & \text { se } & \tilde{X}_{j} \geq X^{*}, \\
=X j, & \text { se } & \tilde{X}_{j} \leq X^{*} .
\end{array}
$$

$\mathrm{B}_{1}$ é o valor atual de mercado dos direitos dos detentores das obrigações se 0 investimento 1 for escolhido e $\mathrm{B}_{2}$ é 0 valor atual de mercado dos detentores das obrigações se 0 investimento 2 for escolhido. Como neste exemplo o valor total da firma, $V$, independe da opção de investimento e também da decisão de financiamento, podemos utilizar o modelo de precificação das opções de Black-Scholes (1973) para calcular os valores do capital de terceiros, $B_{i}$, e do capital próprio, $S_{i j}$, em cada uma dessas opções. ${ }^{41}$

Black-Scholes obtêm a solução para o valor de uma opção de compra européia (uma opção que pode ser exercida somente na data de vencimento) e argumentam que a equação resultante de precificação da opção pode ser utilizada para determinar o valor dos direitos sobre o capital próprio de uma empresa alavancada. Isto é, os acionistas de uma firma como essa podem ser vistos como detendo uma opção de compra européia no valor total da firma com preço de exercício igual a X* (o valor nominal da dívida), que pode ser resgatada na data de vencimento da emissão da dívida. Visto de forma mais simples, os acionistas têm o direito de comprar a firma de volta dos detentores das obrigações pelo preço X* no tempo T. Merton $(1973,1974)$ mostra que, à medida que a variância da distribuição do resultado aumenta, o valor da ação (i.e., a opção de compra) sobe e, como as nossas duas distribuições diferem apenas em suas variâncias, $\sigma_{1}^{2}<\sigma_{2}^{2}$, o valor do capital próprio $S_{1}$ é menor que $S_{2}$. Isso implica em $B_{1}>$ $B_{2}$, já que $B_{1}=V-S_{1}$ e $B_{2}=V-S_{2}$.

Agora que o proprietário-administrador pode vender obrigações ao valor nominal $X^{*}$ nas condições de que os detentores das obrigações acreditaram que seria um direito sobre a distribuição 1 , ele receberá um preço $B_{1}$. Depois de vender as obrigações, a sua participação de capital próprio na distribuição 1 terá o valor $S_{1}$. M as sabemos que $S_{2}$ é maior que $S_{1}$ e, desta forma, o administrador pode se beneficiar mudando o investimento para se favorecer da distribuição 2 de variância superior, redistribuindo, desta forma, a riqueza dos detentores das obrigações para si mesmo. Tudo isso pressupõe, é claro, que os detentores das obrigações não teriam como impedi-lo de mudar o programa de investimentos. Se os detentores das obrigações não puderem fazer isso, e se nota- rem que 0 administrador tem a oportunidade de se apossar da distribuição 2, eles pagarão ao administrador apenas $B_{2}$ pelo direito $X^{*}$, percebendo que o comportamento maximizador do administrador o leva a escolher a distribuição 2. Neste caso, não há redistribuição de riqueza entre os detentores das obrigações e os acionistas (e, em geral, com expectativas racionais, isso nunca ocorrerá) e nenhuma perda de bem-estar. É fácil desenvolver um caso, contudo, no qual esses efeitos sobre o incentivo de fato geram custos reais.

Suponhamos que a distribuição 2 do fluxo de caixa no exemplo anterior tenha um valor esperado, $E\left(X_{2}\right)$, mais baixo que 0 da distribuição 1 . Assim, sabemos que $V_{1}>$ $\mathrm{V}_{2}$, e, se $\Delta \mathrm{V}$, que é dado por:

$$
\Delta V=V_{1}-V_{2}-\left(S_{1}-S_{2}\right)+\left(B_{1}-B_{2}\right),
$$

for suficientemente pequeno em relação à redução do valor das obrigações, 0 valor da ação aumentará. ${ }^{42}$ Reorganizando a expressão para $\Delta \mathrm{V}$, notamos que a diferença entre o capital próprio dos dois investimentos é dada por:

$$
\left(S_{2}-S_{1}\right)=\left(B_{1}-B_{2}\right)-\left(V_{1}-V_{2}\right)
$$

e o primeiro termo do lado direito, $B_{1}-B_{2}$, é a quantia de riqueza "transferida" dos detentores das obrigações e $V_{1}-V_{2}$ é a redução do valor geral da firma. Como sabemos que $B_{1}>B_{2}, S_{2}-S_{1}$ pode ser positivo mesmo apesar de a redução do valor da firma, $V_{1}-V_{2}$, ser positiva. ${ }^{43}$ $M$ ais uma vez, os detentores das obrigações não perderão se forem capazes de identificar a motivação do administrador detentor de capital próprio e a sua oportunidade de optar pelo projeto 2. Eles presumirão que ele escolherá o investimento 2 e, desta forma, não pagarão mais do que $B_{2}$ pelas obrigações quando elas forem emitidas.

Neste exemplo simples, o valor reduzido da firma, $V_{1}-V_{2}$, é o custo de agência resultante da emissão da dívida ${ }^{44}$ e gerado pelo proprietário-administrador. Se ele pudesse financiar o projeto com a sua própria riqueza pessoal, ele claramente escolheria o projeto 1 , já que 0 seu desembolso para o investimento deveria ser igual ao do projeto 2 e o seu valor de mercado, $V_{1}$, seria maior. Essa perda de riqueza, $V_{1}-V_{2}$, é a parcela do "custo residual" do que definimos como custos de agência e é gerada pela cooperação necessária para levantar fundos para fazer o investimento. Uma outra parte importante dos custos de agência são os custos de monitoramento e de concessão de garantias contratuais, cujo papel analisaremos a seguir. 


\section{0 papel dos custos de monitoramento e de concessão de garantias contratuais}

Em princípio, seria possível para os detentores da dívida, por meio da inclusão de várias disposições contratuais, limitar o comportamento dos administradores, o que resultaria em reduções do valor das obrigações. Cláusulas que impõem restrições às decisões da administração relativas a fatores como dividendos, emissões de dívidas futuras ${ }^{45}$ e manutenção do capital ativo não são raras em emissões de dívida. ${ }^{46}$ Para proteger completamente os detentores das obrigações dos efeitos sobre o incentivo, essas cláusulas deveriam ser incrivelmente detal hadas e cobrir a maioria dos aspectos operacionais do empreendimento, incluindo limitações ao risco dos projetos realizados. Os custos envolvidos na elaboração de tais cláusulas, os custos de garantir o seu cumprimento e a rentabilidade reduzida da firma ( resultante da limitação contratual ocasional à capacidade da administração de promover ações ótimas relativas a algumas questões) provavelmente seriam significativos. Com efeito, pelo fato de a administração se manter em um processo decisório contínuo, seria praticamente impossível especificar completamente todas as condições sem que os próprios detentores das obrigações fossem obrigados a assumir as funções do administrador. Todos os custos associados a cláusulas como essas são o que chamamos de custos de monitoramento.

Os detentores das obrigações terão incentivos a se envolver na elaboração dessas cláusulas e no monitoramento das ações do administrador até o ponto em que o custo marginal "nominal" dessas atividades para os detentores das obrigações seja igual aos benefícios marginais que percebem em sua elaboração. Utilizamos aqui a palavra "nominal" porque os detentores das obrigações na verdade não arcarão com esses custos. Se eles reconhecerem a sua existência, el es levarão esses custos em consideração na especificação do preço que pagarão por qualquer direito sobre o capital de terceiros ${ }^{47}$ e, desta forma, o vendedor do direito (o proprietário) arcará com os custos da mesma forma como no caso do capital próprio discutido na Seção 2.

Além disso, o administrador tem incentivos para levar em consideração os custos impostos sobre a firma devido a cláusulas no acordo da dívida, que afetam diretamente os fluxos de caixa futuros da firma, já que reduzem o valor de mercado de seus direitos. Como tanto os custos de monitoramento externos quanto internos são impostos sobre o proprietário-administrador, é de interesse dele assegurar que o monitoramento seja realizado da forma menos custosa. Suponha, por exemplo, que os detentores das obrigações (ou acionistas externos) considerassem que compensa produzir demonstrativos financeiros detal hados como os contidos nos relatórios contábeis comumente divulgados como uma forma de monitorar o administrador. Se o próprio administrador puder elaborar essas informações a custos inferiores do que os detentores das obrigações ( talvez por já estar coletando grande parte dos dados que eles desejam para os seus próprios fins de tomada de decisões internas), compensaria para ele concordar em incorrer com o custo de fornecer esses relatórios e ter a sua exatidão validada por um auditor independente externo. Este é um exemplo do que chamamos de custos de concessão de garantias contratuais. ${ }^{48,}, 49$

\section{Custos de reorganização e falência}

Argumentamos na Seção 5 que, à medida que o capital de terceiros na estrutura de capital aumenta al ém de um determinado ponto, os custos marginais de agência do capital de terceiros começa a dominar os custos marginais de agência dos acionistas externos e o resultado disso é o fenômeno geralmente observado da utilização simultânea tanto do capital de terceiros quanto do capital próprio externo. Antes de abordar essas questões, contudo, consideramos aqui o terceiro principal componente dos custos de agência do capital de terceiros que ajuda a explicar por que o capital de terceiros não domina completamente as estruturas de capital - a existência dos custos de reorganização e falência.

É importante enfatizar que falência e liquidação são eventos muito diferentes. A definição legal de falência é difícil de ser especificada com precisão. Em geral, ela ocorre quando a firma não tem como satisfazer um pagamento atual de uma obrigação de dívida $a^{50}$ ou quando uma ou mais disposições contratuais de falência for violada pela firma. N este caso, os acionistas perdem todos os direitos pela firma ${ }^{51}$ e a perda restante, a diferença entre o val or nominal da dívida e o valor de mercado da firma, é assumida pelos detentores das obrigações. A liquidação dos ativos da firma ocorrerá somente se o valor de mercado dos fluxos de caixa futuros gerados pela firma for menor do que o custo de oportunidade dos ativos, i.e., a soma dos valores que poderiam ser realizados se os ativos fossem vendidos em partes.

Se não houver custos associados ao evento chamado falência, o valor de mercado total da firma não será afetado pelo aumento da probabilidade de sua incidência. Contudo, écustoso, se não impossível, elaborar contratos representando direitos sobre uma firma que delineiem claramente os direitos dos detentores de todas as con- 
tingências possíveis. Desta forma, mesmo na ausência de efeitos adversos sobre o incentivo na expansão do capital de terceiros relativos ao capital próprio de uma firma, a utilização desses resgates fixos seria limitada pelos custos inerentes da definição e da garantia de cumprimento dessas cláusulas. As firmas incorrem diariamente em obrigações com fornecedores, empregados, diferentes categorias de investidores, etc. Enquanto a firma estiver prosperando, a adjudicação de direitos raramente representa um problema. Quando a firma tem dificuldades em cumprir algumas dessas obrigações, contudo, a questão da prioridade desses direitos pode levar a sérios problemas. Isso fica mais evidente no caso extremo no qual a firma é forçada a abrir falência. Se a falência não incidisse em custos, a reorganização seria acompanhada de um ajuste dos direitos de várias partes e o negócio poderia, se pudesse ser comprovado que isso seria do interesse dos requerentes, simplesmente continuar em operação (apesar de talvez sob uma nova administração). ${ }^{52}$

$\mathrm{N}$ a prática, a falência tem custos, geralmente envolvendo um processo de adjudicação que por si só consome uma parcela do val or restante dos ativos da firma. Desta forma, o custo da falência será de interesse dos compradores potenciais de obrigações da firma, uma vez que a sua existência reduzirá os seus lucros no caso de falência; Esses são exemplos dos esforços cooperativos entre indivíduos (apesar de, neste caso, talvez "não cooperativos" fosse um termo melhor). 0 preço que os compradores estarão dispostos a pagar pelas obrigações de dívida desta forma será inversamente proporcional à probabilidade da incidência desses custos, i.e., à probabilidade de falência. Utilizando uma versão do argumento desenvolvido acima para os custos de monitoramento, pode ser demonstrado que o valor total da empresa será reduzido e o proprietário-administrador, detentor do capital próprio, arcará com todo o efeito sobre a riqueza dos custos da falência se os detentores das obrigações fizerem estimativas imparciais de sua extensão no momento em que inicialmente compram as obrigações. ${ }^{53}$

Estudos empíricos da extensão dos custos de fal ência são praticamente inexistentes. Warner (1975), em um estudo de 11 falências de estradas de ferro entre 1930 e 1955 estima que os custos médios da falência, ${ }^{54}$ como uma fração do valor da firma três anos antes da falência, são de $2,5 \%$ (em uma faixa de 0,4 a $5,, 9 \%$ ). Os custos médios em dólares foram de $\$ 1,88$ milhão. Essas duas medidas parecem consideravelmente pequenas e estão de acordo com a nossa crença de que os custos de falência, por si só, têm poucas chances de constituírem o principal determinante das estruturas de capital corpo- rativo. Também é interessante notar que a quantia anual de fundos inadimplentes caiu significativamente desde 1940. [Veja Atkinson (1967).] U ma explicação possível para esse fenômeno é que as firmas estão recorrendo a fusões para evitar os custos da falência. Essa hipótese parece ainda mais razoável se, como costuma ser o caso, os custos de reorganização representarem apenas uma parcela dos custos associados com a falência.

Em geral as receitas ou os custos operacionais da firma não são independentes da probabilidade de falência e, portanto, da estrutura de capital da firma. À medida que a probabilidade de fal ência aumenta, tanto os custos operacionais quanto as receitas da firma são negativamente afetados, e al guns desses custos podem ser evitados por uma fusão. Por exemplo, uma firma com uma grande probabilidade de falência também descobrirá que precisa pagar salários mais al tos para induzir os executivos a aceitar um maior risco de desemprego. Além disso, no caso das indústrias de al guns tipos de bens duráveis, a função de demanda pelo produto da firma não será independente da probabilidade de falência. A indústria de computadores é um bom exemplo disso. No caso, o bem-estar do comprador depende em uma extensão significativa, da capacidade de manter o equipamento e do desenvolvimento contínuo de hardware e software. Além disso, o proprietário de um grande computador costuma receber benefícios dos desenvolvimentos de software feitos por outros usuários. Desta forma, se o fabricante sair do negócio, interromper seu serviço de assistência ao software ou perder seus especialistas de desenvolvimento devido a dificuldades financeiras, o valor do equipamento para os seus usuários cairá. Os compradores desses serviços terão um interesse contínuo na viabilidade do fabricante, de forma similar a um detentor de obrigações, exceto que os benefícios dos compradores virão na forma de serviços contínuos a preços mais baixo em vez do pagamento de juros. Instalações de serviços e peças de reposição para automóveis e maquinário representam mais dois exemplos disso.

Em resumo, quando os custos de agência associados com a dívida ${ }^{55}$ consistirem de:

(1) a perda de oportunidade de riqueza causada pelo impacto da dívida (ou capital de terceiros) sobre as decisões de investimento da firma;

(2) as despesas de monitoramento e com a concessão de garantias contratuais incorridas pel os detentores de obrigações e pelo proprietário-administrador (i.e., a firma);

(3) os custos de reorganização e falência. 


\section{Por que os custos de agência da dívida são incorridos?}

Argumentamos que o proprietário-administrador arca com todos os efeitos dos custos de agência da dívida sobre a riqueza e se favorece dos ganhos de sua redução. Desta forma, os custos de agência associados à divida discutidos acima tenderão, na ausência de outros fatores mitigadores, a desencorajar a utilização de capital de terceiros. Quais são os fatores que incentivam a sua utilização?

Um fator é o subsídio fiscal para os pagamentos de juros (isso não explicará as ações preferenciais nas quais os dividendos não podem deduzidos dos impostos. $)^{56}$. Modigliani e Miller (1963) original mente demonstraram que a utilização de dívidas perpétuas livres de risco aumentarão o valor total da firma (ignorando-se os custos de agência) em uma quantia igual a $r B$, onde $z$ é a é a taxa média e marginal de imposto de renda e $B$ é o valor de mercado da dívida. Fama e Miller (1972, Capítulo 4) demonstram que, no caso de dívidas arriscadas, o valor da firma aumentará com o valor de mercado do subsídio fiscal (incerto) para os pagamentos de juros. Mais uma vez, esses ganhos serão inteiramente resultantes do incentivo de utilizar a dívida até o ponto em que os benefícios marginais do subsídio fiscal sobre a riqueza são exatamente iguais ao efeitos marginais sobre a riqueza dos custos de agência discutidos acima.

Contudo, mesmo na ausência desses benefícios fiscais, a dívida seria utilizada se a capacidade de explorar oportunidades de investimento potencialmente lucrativas for limitada pelos recursos do proprietário. Se o proprietário de um projeto não puder levantar capital, ele sofrerá a perda de oportunidade representada pelo incremento de valor oferecido a ele pelas oportunidades de investimento adicionais. Assim, apesar de ele arcar com os custos de agência das vendas do capital de terceiros, ele considerará desejável incorrer com os custos para obter capital adicional se os incrementos marginais de riqueza resultantes dos novos projetos de investimentos forem maiores do que os custos marginais de agência da dívida e esses custos de agência são, por sua vez, menores do que os resultantes da venda de capital próprio adicional que discutimos na Seção 2. Além disso, essa solução é ótima do ponto de vista social. Contudo, na ausência de subsídios fiscais para a dívida, esses projetos devem ser únicos a essa firma ${ }^{57}$ ou, de outra forma, eles seriam escolhidos por outros empresários competitivos (talvez os novos) que possuem a riqueza pessoal necessária para financiar plenamente os projeto ${ }^{58} \mathrm{e}$, desta forma, capaz de evitar a existência do capital de terceiros ou de acionistas externos.

\section{UMA TEORIA DA ESTRUTURA DE PROPRIEDADE CORPORATIVA}

$\mathrm{N}$ as seções anteriores discutimos a natureza dos custos de agência associados a direitos externos sobre a firma tanto em termos de capital de terceiros quanto de capital próprio. 0 nosso propósito aqui éintegrar esses conceitos aos fundamentos de uma teoria da estrutura de propriedade corporativa. Utilizamos o termo "estrutura de propriedade" em vez de "estrutura de capital" para salientar o fato de que as variáveis cruciais a serem definidas não se referem apenas às quantias de capital de tercei ros e de capital próprio, mas também das parcelas de capital próprio e de terceiros detidas pelo administrador. Desta forma, para uma firma de um determinado tamanho, queremos uma teoria que determine três variáveis: ${ }^{59}$

$\mathrm{S}_{\mathrm{i}}$ : capital próprio interno (detido pelo administrador), $\mathrm{S}_{0}$ : capital próprio externo (detido por qualquer pessoa fora da empresa),

B: capital de terceiros (detido por qualquer pessoa fora da empresa).

$O$ valor de mercado total do capital próprio é $S=S_{i}+S_{0} e$ 0 valor de mercado total da firma é $V=S+B$. Além disso, também desejamos ter uma teoria que determina o tamanho ótimo da firma, i.e., o seu nível de investimento.

\section{Determinação da razão ótima entre o capital próprio externo e o capital de terceiros}

Consideraremos primeiro a determinação da razão ótima entre o capital próprio externo e o capital de terceiros, $\mathrm{S}_{0} / \mathrm{B}$. Para tanto, manteremos constante o tamanho da firma. V, o valor real firma para um determinado tamanho, dependerá dos custos de agência incorridos, de forma que utilizamos, como o índice de tamanho, V*, o valor da firma em uma determinada escal a quando os custos de agência são zero. Por enquanto, também mantemos constante a quantia de financiamento externo $\left(B+S_{0}\right)$. Considerando que uma quantia especificada de financiamento $\left(B+S_{0}\right)$ deve ser obtida externamente, o nosso problema é determinar a parcela ótima $\mathrm{E}^{*} \equiv \mathrm{S}_{0} * /\left(\mathrm{B}+\mathrm{S}_{0}\right)$ a ser financiada com o capital próprio.

Argumentamos acima que: (1) se os mercados de capital forem eficientes (i.e., caracterizados por expectativas racionais), os preços dos ativos como capital de terceiros e capital próprio externo refletirá as estimativas imparciais dos custos de monitoramento eredistribuições que a relação de agência causará e (2) o proprietário-administrador que vende a sua participação arcará com esses custos de agência. Desta forma, do ponto de vista do proprietário- 
administrador, a proporção ótima dos fundos externos a serem levantados a partir de acionistas externos (em oposição ao capital de terceiros) para um determinado nível de capital próprio interno éE, que resulta em custos totais mínimos de agência.

A Figura 5 apresenta uma segmentação dos custos de agência em dois componentes separados: $A_{S_{0}}(E)$ são os custos totais de agência (uma função de $E$ ) associados à 'exploração' dos detentores de capital próprio externo por parte do proprietário-administrador e $A_{B}$ ( $E$ ) são os custos totais de agência associados com a presença de capital de terceiros na estrutura de propriedade. $A_{T}(E)=A_{S_{0}}(E)+$ $A_{B}(E)$ é o custo total de agência.

Considere a função $A_{S_{0}}(E)$. Quando $E^{*} \equiv S_{0}^{*} /\left(B+S_{0}\right)$ é zero, i.e., na ausência de acionistas externos, os incentivos do administrador para explorar o uso de capital próprio externo está no nível mínimo (zero) já que as variações do val or do capital próprio total são iguais às variações do capital próprio do administrador. ${ }^{60} \mathrm{~A}$ medida que $\mathrm{E}$ aumenta para 100 por cento os incentivos do administrador para explorar o capital próprio externo aumenta e, em conseqüência, os custos de agência $A_{S 0}(E)$ também aumentam.

Os custos de agência associados à existência de capital de terceiros, $A B(E)$, são compostos principalmente das reduções de valor da firma e dos custos de monitoramento causados pelo incentivo do administrador de realocar a riqueza dos detentores de obrigações para si próprio por meio do aumento do valor dos direitos sobre o capital próprio. Eles atingem o máximo quando todos os fundos externos são obtidos a partir do capital de terceiros, i.e., onde $\mathrm{S}_{0}=\mathrm{E}=0$. À medida que a quantia de capital de terceiros cai a zero, esses custos também caem a zero porque, à medida que $E$ passa para 1 , o incentivo do administrador para real ocar a riqueza dos detentores de obrigações para si próprio diminui. Esses incentivos diminuem por duas razões: (1) a quantia total de capital de terceiros diminui e, em conseqüência, fica mais difícil transferir qualquer determinada quantia dos detentores de obrigações e (2) a participação do administrador de qualquer realocação real izada se reduz, já que So está aumentando e, portanto, Si $/\left(S_{0}+S_{i}\right)$, a participação do administrador no capital próprio total, está em queda.

A curva $A_{T}(E)$ representa a soma dos custos de agência da várias combinações de uso de capital próprio externo e financiamento com dívidas e, se $A_{S_{0}}(E)$ e $A_{B}(E)$ estiverem na posição que esboçamos no gráfico, o custo total mínimo de agência para um determinado tamanho de empresa e o financiamento externo ocorrerão em algum ponto, como AT $\left(E^{*}\right)$, com uma combinação de capital de terceiros e capital próprio. ${ }^{61}$

Figura 5 - Custos totais de agência, $A_{T}(E)$, como uma função da razão entre o capital próprio externo e o financiamento externo total, $E^{*} \equiv S_{0}^{*} /\left(B+S_{0}\right)$, para um determinado tamanho da firma, $V^{*}$, e determinadas quantias totais de financiamento externo $\left(B+S_{0}\right)$
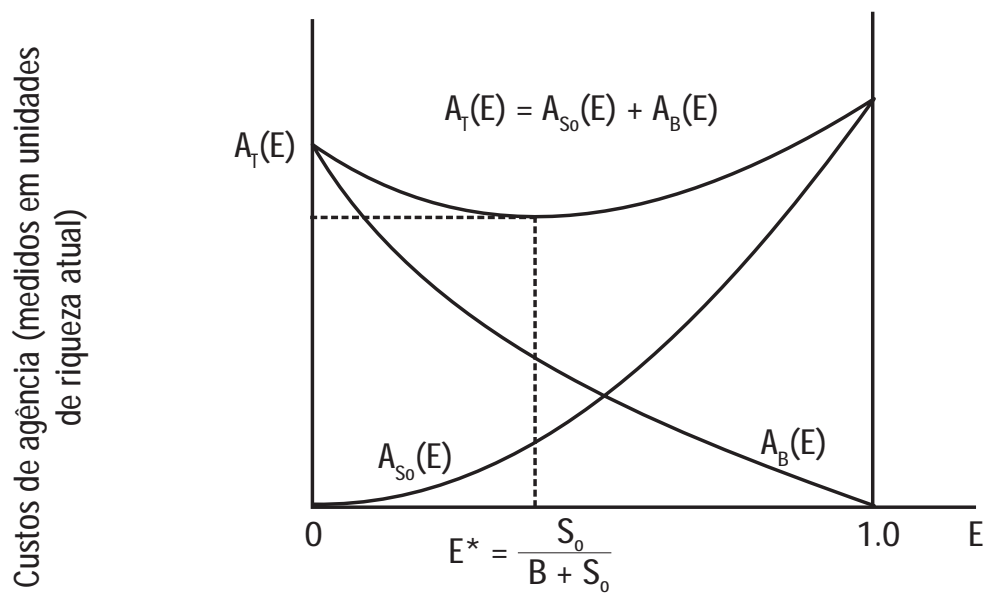

Parcela do financiamento externo obtida do capital próprio

Nota: $A_{S 0}(E) \equiv$ custos de agência associados ao capital próprio externo, $A_{B}(E) \equiv$ custos de agência com o capital de terceiros, $B$. $A_{T}\left(E^{*}\right)$ = custos totais mínimos de agência na parcela ótima de financiamento externo $E^{*}$. 
U ma advertência. Antes de prosseguir, salientamos que a questão referente aos formatos exatos das funções esboçadas na Figura 5 e várias outras discutidas abaixo é essencialmente uma questão em aberto no presente momento. Ao final, o formato dessas funções é uma questão de fato e só pode ser determinado por evidências empíricas. Esboçamos al guns argumentos a priori que acreditamos levar a al gumas hipóteses plausíveis sobre o comportamento do sistema, mas confessamos que estamos longe de compreender as várias sutilezas conceituais do problema. Estamos razoavelmente confiantes em relação aos nossos argumentos sobre os sinais das primeiras derivadas das funções, mas as segundas derivadas também são importante para a solução final e muito mais estudo (tanto teórico quanto empírico) será necessário antes de termos plena convicção em relação a esses parâmetros. Esperamos que o trabalho de outros, além do nosso próprio, possa iluminar essa questão. Além disso, suspeitamos que os resultados desses esforços suscitarão revisões dos detal hes que apresentamos a seguir. Acreditamos ser de interesse delinear o quadro conceitual geral para demonstrar, mesmo se meramente de forma simplificada, como as principais peças do quebra-cabeças se encaixam em uma estrutura coerente.

\section{Efeitos da escala do financiamento externo}

Para investigar os efeitos do aumento da quantia de financiamento externo, $\mathrm{B}+\mathrm{S}_{0}$, e, desta forma, reduzir a quantia de capital próprio detido pelo administrador, Si, continuamos a manter constante a escala da firma, $V^{*}$. A Figura 6 apresenta um gráfico das funções de custo de agência, $A_{S 0}(E), A_{B}(E)$ e $A_{T}(E)=A_{S 0}(E)+A_{B}(E)$, para dois níveis diferentes de financiamento externo. Definimos o índice da quantidade de financiamento externo como:

$$
K=\left(B+S_{o}\right) / V^{*},
$$

e consideramos dois diferentes níveis possíveis de financiamento externo, $\mathrm{K}_{0}$ e $\mathrm{K}_{1}$, para uma determinada escala da firma, tal qual $K_{0}<K_{1}$.

A quantidade de capital próprio externo aumenta, os direitos parciais do proprietário sobre a firma, $\alpha$, diminuem. Desta forma, ele será induzido a receber benefícios não pecuniários adicionais da empresa porque a sua partici pação no custo é reduzida. Isso também aumenta os benefícios marginais provenientes das atividades de monitoramento e, desta forma, tenderá a aumentar o nível ótimo do monitoramento. Esses dois fatores farão com que o lugar geométrico dos custos de agência, $A_{S_{0}}(E ; K)$, se desloque para cima à medida que a parcela do financiamento ex- terno, K, aumenta. Isso é plotado na Figura 6 pelas duas curvas representan do os custos de agência do capital próprio, uma para o nível inferior de financiamento externo, $A_{S_{0}}\left(E ; K_{0}\right)$, e a outra para o nível superior de financiamento externo, $A_{s_{0}}\left(E_{;} K_{1}\right)$. O lugar geométrico da última curva é acima da primeira curva em todos os pontos, com exceção na origem, quando ambas estão em 0.

De forma similar, o custo de agência do capital de terceiros aumentará à medida que a quantia de financiamento externo aumenta. Isso significa que o lugar geométrico de $A_{B}\left(E ; K_{1}\right)$ para um al to financiamento externo, $K_{1}$ estará acima do lugar geométrico de $A_{B}\left(E ; K_{0}\right)$ para um baixo financiamento externo, $K_{0}$, já que a quantia total de recursos que podem ser transferidos dos detentores de obrigações aumenta à medida que a quantia total do capital de terceiros aumenta. Entretanto, como os custos são zero quando o capital de terceiros é zero tanto para $K_{0}$ quanto para $K_{1}$, as intersecções das curvas $A_{B}(E ; K)$ coincidem no eixo da direita.

0 efeito líquido da maior utilização do financiamento externo considerando as funções de custo aplicadas na Figura 6 é: (1) aumentar os custos totais de agência de AT $\left(E^{*} ; K_{0}\right)$ a AT $\left(E^{*} ; K_{1}\right)$ e (2) aumentar a parcela ótima de fundos externos obtidos por meio da venda de capital próprio externo. Esboçamos essas funções meramente para fins de ilustração e não pretendemos especular neste momento sobre a forma exata de $E^{*}(K)$, que descreve os efeitos gerais do aumento do financiamento externo sobre as quantidades relativas de capital de terceiros e próprio.

O lugar geométricos dos pontos, AT $\left(E^{*} ; K\right)$, onde os custos de agência são minimizados (não desenhados na Figura 6), determina $E^{*}(K)$, as proporções ótimas de capital próprio e capital de terceiros a serem utilizadas na obtenção de fundos externos à medida que a parcela de fundos externos, K, varia de 0 a 100 por cento. A linha cheia da Figura 7 é uma representação dos custos totais mínimos de e agência como uma função da quantia de financiamento externo para uma firma com escala $V_{0}{ }^{*}$. A linha pontilhada indica os custos totais de agência para uma firma maior com escala $\mathrm{V}_{1}{ }^{*}>\mathrm{V}_{0}{ }^{*}$. Desta forma, a nossa hipótese é que, quando mais a firma crescer, maiores são os custos totais de agência já que provavelmente a função de monitoramento será inerentemente mais difícil e dispendiosa em uma organização maior.

\section{Risco e demanda por financiamento externo}

0 modelo que utilizamos para explicar a presença de acionistas minoritários e capital de terceiros na estrutura de capital de empresas implica que o proprietário-admi- 
nistrador, caso recorra a qual quer financiamento externo, terá toda a sua riqueza investida na firma. A razão para isso é que ele pode, com isso, evitar os custos de agência impostos pelo financiamento externo adicional. I sso sugereque ele não recorreria ao financiamento externo até ter investido 100 por cento de sua riqueza pessoal na firma uma implicação que não é compatível com o que geralmente observamos. A maioria dos proprietários-administradores mantém a riqueza pessoal em diferentes formas e alguns têm apenas uma parcela relativamente pequena de sua riqueza investida na empresa que administram. ${ }^{62} \mathrm{~A}$ diversificação por parte dos proprietários-administradores podem ser explicada pela aversão ao risco e pela seleção ótima do portfólio.

Se os retornos dos ativos não forem perfeitamente correlacionados, um indivíduo pode reduzir o nível de risco dos retorno em seu portfólio distribuindo a sua riqueza entre vários diferentes ativos, i.e., por meio da diversificação. ${ }^{63}$ Desta forma, um administrador que investe toda a sua riqueza em uma única firma (de sua propriedade) em geral arcará com uma perda de bem-estar (se for avesso ao risco) porque está assumindo mais riscos do que o necessário. Ele, naturalmente, estará disposto a pagar para evitar esse risco, e os custos que ele deve incorrer para realizar essa diversificação serão os custos de agência esboçados acima. Ele sofrerá uma perda de riqueza à medida que reduzir a sua parcela de propriedade já que acionistas e detentores de obrigações potenciais levarão em consideração os custos de agência. Contudo, o desejo do administrador de evitar o risco contribuirá para a sua opção de se tornar um acionista minoritário.

\section{Determinação da quantia ótima de financiamento externo, $K^{*}$}

Vamos supor que o proprietário de um projeto (i.e., o proprietário de uma firma prospectiva) tenha riqueza suficiente para financiar todo o projeto sozinho. A escala ótima da empresa é, então, determinada pela condição de que $\Delta \mathrm{V}-\Delta \mathrm{l}=0$. Em geral, se os retornos para a firma forem incertos, o proprietário-administrador pode aumentar 0

Figura 6 - Funções do custo de agência e capital próprio externo ótimo como uma parcela do financiamento externo total, E* (K), para dois níveis diferentes de financiamento externo, $\mathrm{K}$, para uma firma de um determinado tamanho, $\mathrm{V}^{*}: \mathrm{K}_{1}>\mathrm{K}_{0}$

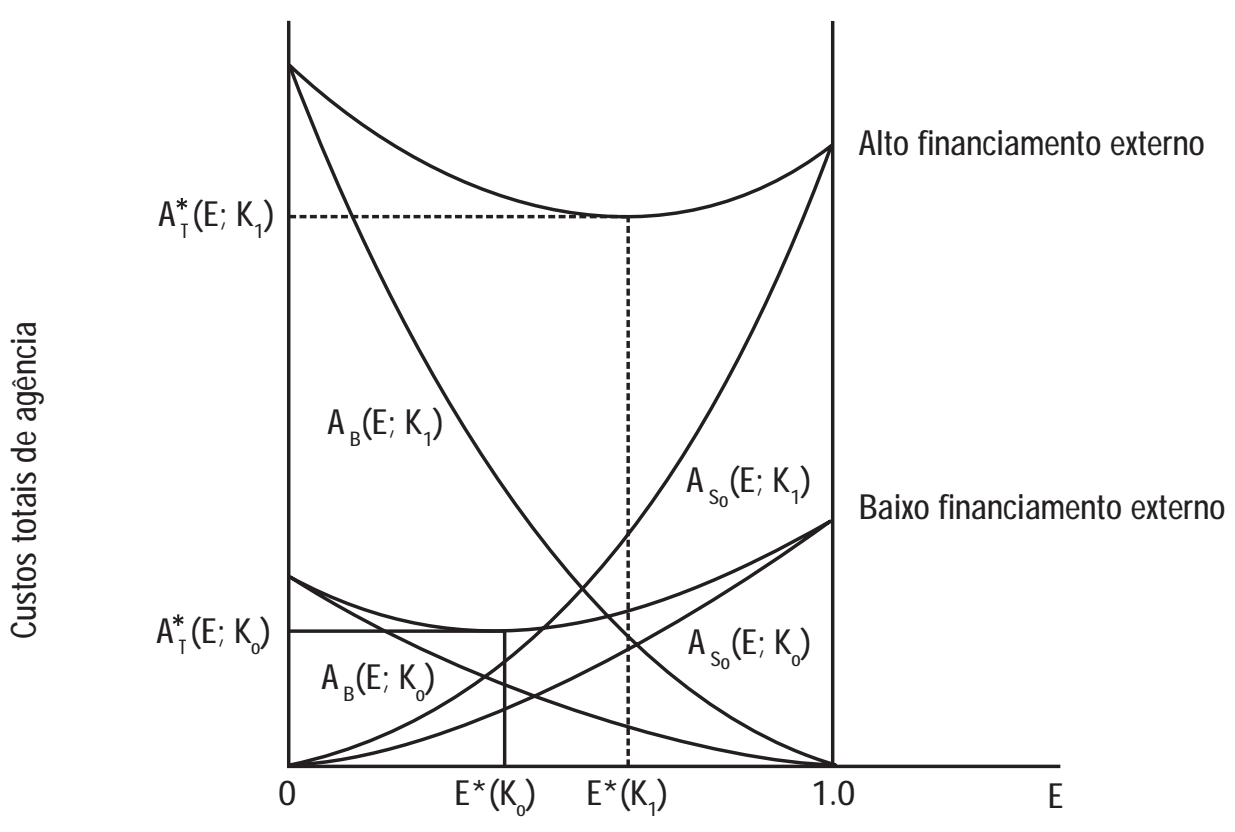

Parcela do financiamento externo obtida do capital próprio 
seu bem-estar vendendo parte da firma na forma de capital de terceiros ou capital próprio e reinvestindo os lucros em outros ativos. Se ele fizer isso com a combinação ótima de capital de terceiros e capital próprio (como na Figura 6) a redução total da riqueza que ele incorrerá é dada pela função de custo de agência, AT ( $\left.E^{*}, K ; V^{*}\right)$ na Figura 7. As funções $A T\left(E^{*}, K ; V^{*}\right)$ terão a forma de $S$ (como apresentado no gráfico) se os custos totais de agência para uma empresa de determinada escal a aumentarem em uma taxa crescente em baixos níveis de financiamento externo e a uma taxa decrescente para al tos níveis de financiamento externo à medida que o monitoramento impõe cada vez mais restrições às ações do administrador.

A Figura 8 mostra os custos marginais de agência como uma função de $K$, a parcela da firma financiada com fundos externos supondo que a função do custo total de agência seja como a plotada na Figura 7 e supondo que a escala da firma seja fixa. A demanda por parte do proprietárioadministrador por financiamento externo é mostrada pela outra curva da Figura 8. Essa curva representa o valor marginal da diversificação crescente que 0 administrador pode obter por meio da redução de seus direitos de proprietário e montando um portfólio com nível ótimo de diversificação. Ele é medido pela quantia que ele pagaria para poder reduzir os seus direitos de propriedade em uma unidade monetária para aumentar a sua diversificação. Se a liquidação de parte de sua participação tam- bém influenciar o conjunto de consumo do proprietárioadministrador, a função de demanda plotada na Figura 8 também incorpora 0 valor marginal desses efeitos. A intersecção desses dois valores determina a parcela ótima da firma a ser mantida por outsiders, o que, por sua vez, determina os custos totais de agência gerados pelo proprietário. Esta solução representa o ótimo de Pareto; não há como reduzir os custos de agência sem piorar a situação de al guém.

\section{Determinação da escala ótima da firma}

A pesar de os detal hes da solução da escal a ótima da firma serem complexos quando permitimos a emissão de capital de terceiros, capital próprio e monitoramento e concessão de garantias contratuais, a estrutura geral da solução é análoga ao caso no qual o monitoramento e a concessão de garantias contratuais são permitidas para o exemplo do capital próprio externo (veja a Figura 4).

Se for ótimo emitir qualquer capital de terceiros, a trajetória de expansão, levando em consideração essas oportunidades, deve ficar acima da curvaZG da Figura 4. Se essa nova trajetória de expansão se localizar em qualquer ponto à direita da curva de indiferença que passa pelo ponto G, o capital de terceiros será utilizado no pacote ótimo de financiamento. Além disso, a escala ótima da firma será determinada pelo ponto no qual essa nova trajetória de expansão tocar o ponto mais al to da curva

Figura 7 - Custos totais de agência como uma função da parcela da firma financiada por direitos externos para dois tamanhos de firma, $\mathrm{V}_{1}^{*}>\mathrm{V}_{0}{ }^{*}$

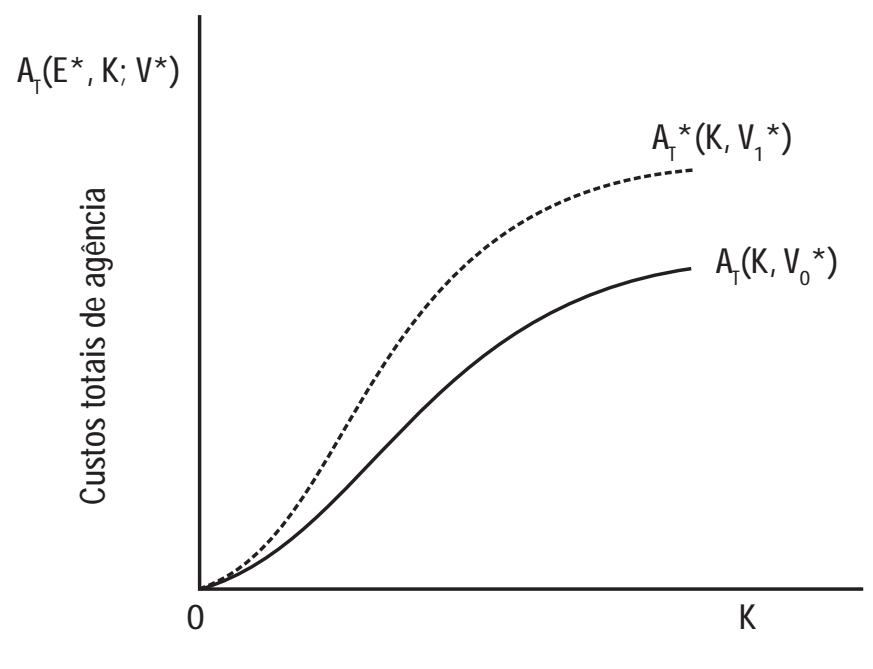

Parcela da firma financiada por direitos externos 
de indiferença. N esta situação, o nível resultante do bemestar do proprietário-administrador deve, em conseqüência, ser mais alto.

\section{QUALIFICAÇÕES E EXTENSÕES DA ANÁLISE}

\section{Aspectos multiperíodos do problema do agência}

Presumimos ao longo da nossa análise estarmos lidando somente com uma única decisão de investimentofinanciamento por parte do empresário e ignoramos as questões associadas aos incentivos que afetam as decisões futuras de investimento-financiamento que podem surgir após o conjunto inicial de contratos ser fechado entre 0 empresário-administrador, acionistas externos e detentores de obrigações. Tratam-se de questões importantes que deixamos para análise futura. ${ }^{64} \mathrm{~A}$ sua solução sem dúvida implicará em algumas modificações nas conclusões da análise de decisão única. Parece-nos claro, por exemplo, que a expectativa das vendas futuras do capital próprio externo e do capital de terceiros alterará os custos e os benefícios que o administrador levará em consideração para tomar decisões para beneficiar a si mesmo à custa (no curto prazo) dos acionistas externos e detentores de obrigações atuais. Se ele desenvolver uma reputação de tender a transações como essas, el e pode esperar uma influência negativa nas condições nas quais ele poderá obter capital futuro de fontes externas. Isso tenderá a aumentar os benefícios associados à "santidade" e tenderá a reduzir a quantia dos custos de agência. Considerando a vida finita de qualquer pessoa, contudo, esse efeito não pode reduzir os custos a zero, porque em algum ponto esses custos futuros começarão a ter um peso maior sobre os seus sucessores e, desta forma, os benefícios para ele de agir em interesse próprio aumentarão. ${ }^{65}$ Além disso, geralmente, será impossível para ele assegurar totalmente aos investidores externos que o seu sucessor seguirá as suas políticas.

\section{0 problema do controle e os custos de agência do proprietário externo}

0 leitor atento notará que em nenhum momento da análise até então levamos em consideração muitos dos detaIhes da relação entre o proprietário parcial-administrador e os acionistas e detentores de obrigações externos. $M$ ais especificamente, pressupomos que todo o capital próprio externo não tenha direito a voto. Se esse capital próprio tiver direito a voto, o administrador se interessará mais pelos efeitos sobre o seu bem-estar de longo-prazo proveniente da redução de sua responsabilidade parcial abaixo do ponto no qual el e perde o controle efetivo da empresa. Isto é, abaixo do ponto em que passa a ser possível para os detentores de capital próprio externo demiti-lo. U ma anál ise completa dessa questão demandará uma cuidadosa

Figura 8 - Determinação da quantia ótima de financiamento externo, $K^{*}$, para uma firma de determinada escala
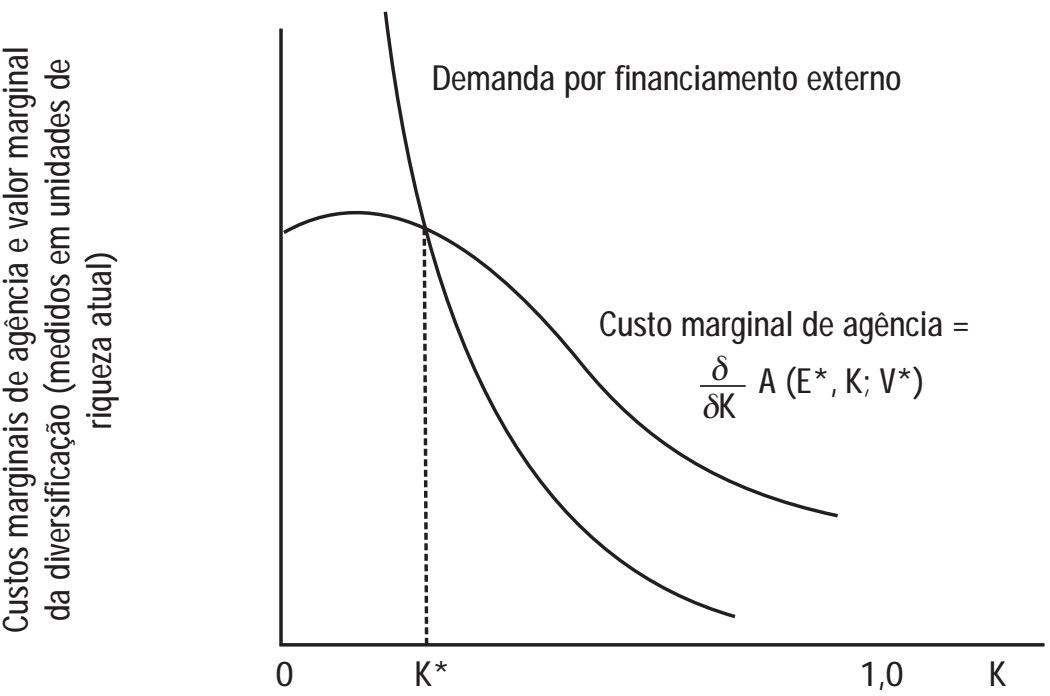

Parcela da firma financiada por direitos externos 
especificação dos direitos contratuais envolvidos em ambos os lados, o papel do consel ho de administração e os custos de coordenação (agência) gerados pel os acionistas na implementação demudanças nas políticas. Esteúltimo ponto envolve uma anál ise da distribuição dos direitos de propriedade externa. Em resumo, várias forças determinam a distribuição de equilíbrio para a propriedade externa. Se os custos para reduzir a dispersão da propriedade forem menores do que os benefícios a serem obtidos da redução dos custos de agência, compensará a al gum indivíduo ou grupo de indivíduos comprar ações no mercado para reduzir a dispersão da propriedade. Testemunhamos ocasionalmente esses conflitos pelo controle que envolvem compras diretas no mercado, ofertas públicas e bataIhas de procuradores. Análises posteriores dessas questões serão deixadas para o futuro.

\section{Uma observação sobre a existência de capital interno de terceiros e algumas conjecturas sobre a utilização de instrumentos financeiros conversíveis}

Fomos questionados ${ }^{66}$ por que o capital de terceiros mantido pelo administrador (i.e., "capital interno de terceiros") não foi incluído na nossa análise. Fomos até o momento incapazes de incorporar formalmente essa dimensão na nossa análise de forma satisfatória. Trata-se de uma boa pergunta, que sugere al gumas extensões potencialmente importantes da análise. Por exemplo, ela sugere uma forma não dispendiosa para o proprietário-administrador que detém tanto capital próprio quanto dívidas em aberto de eliminar uma grande parcela dos custos de agência (talvez todos) do capital de terceiros. Se ele se comprometer em contrato a manter uma parcela do capital de terceiros total igual à sua propriedade parcial do capital próprio total, ele não teria nenhum incentivo para realocar a riqueza dos detentores do capital de terceiros aos acionistas. Considere o caso em que:

$$
B_{i} / S_{i}=B_{o} / S_{o},
$$

Em que Si, e So, mantêm a definição anterior, Bi é o valor em unidades monetárias do capital interno de terceiros mantido pelo proprietário-administrador e Bo é o capital de terceiros mantido pelos outsiders. N este caso, entre os detentores de capital de tercei ros e capital próprio, o efeito líquido sobre o valor total de sua participação na firma será zero. Desta forma, o seu incentivo para promover realocações como essas será zero. ${ }^{67}$

Por que, então, não observamos práticas ou contratos formais que concretizam essa el iminação ou redução dos custos de agência do capital de terceiros? Talvez isso ocor- ra em firmas menores de capital fechado (não tentamos obter esse tipo de dados), mas, para empresa maiores, de propriedade difusa, a prática não parece ser comum. Acreditamos que uma razão para isso seja, em al guns aspectos, os direitos que o administrador tem sobre a firma na forma de seu contrato salarial apresenta algumas das características do capital de terceiros. ${ }^{68}$ Caso se provar verdadeiro, isso implica que, mesmo com participação zero dos direitos formais sobre o capital de terceiros, ele ainda terá uma participação positiva de um direito sobre algo similar ao capital de terceiros, o que pode satisfazer à condição (4). 0 problema, no caso, é quequal quer análise formal dessa questão requer uma compreensão muito mais profunda da relação entre a participação formal de capital de terceiros e o contrato salarial; i.e., o contrato salarial equivale a qual quantia de capital de terceiros?

Essa linha de argumentação também sugere algumas outras questões interessantes. Suponha que as características implícitas do capital deterceiros no contrato sal arial do administrador resultem em uma situação equival ente a:

$$
B_{i} / S_{i}>B_{o} / S_{o}
$$

N este caso, ele teria incentivos para mudar as características operacionais da firma (i.e., reduzir a variância da distribuição de resultados) para transferir riqueza dos acionistas aos detentores de capital de terceiros, o oposto da situação analisada na Seção 4. Além disso, isso parece englobar parte das preocupações normal mente expressas em relação ao fato de que os administradores de grandes empresas de capital aberto parecem se comportar de forma avessa ao risco em detrimento dos detentores do capital próprio. Uma solução possível para isso poderia ser estabelecer sistema de remuneração e incentivos para o administrador ou conceder a ele opções sobre ações que Ihe darão o direito sobre o limite inferior da distribuição dos resultados. Este também parece ser um fenômeno comumente observado.

Esta análise também sugere al gumas questões adicionais referentes aos custos e aos benefícios associados à utilização de direitos financeiros mais complexos, como dívida conversível, títulos conversíveis em ações, ações preferenciais conversíveis em ordinárias que ainda não analisamos formalmente. Dívida conversível, títulos conversíveis em ações e ações preferenciais conversíveis em ordinárias apresentam al gumas das características de ações sem direito a voto, apesar de poderem ser convertidas a ações com direito a voto em determinadas condições. Alchian-Demsetz (1972) fornecem uma análise interessante da utilização de ações sem direito a voto. 
Eles argumentam que al guns acionistas que acreditam no tal ento e na capacidade de julgamento do administrador desejarão se proteger contra a possibilidade de outros acionistas assumirem o controle e limitarem as ações do administrador (ou demiti-lo). Considerando que o mercado de títulos proíbe a utilização de ações sem direito a voto por empresas negociáveis na bolsa de valores, a utilização de títulos de opções pode ser um bem substituto para esses direitos.

Além disso, títulos conversíveis representam um direito sobre o limite inferior da distribuição dos resultados e os títulos conversíveis em ações podem ser considerados valore mobiliários com títul os conversíveis incorporados. A parentemente os efeitos dos títulos conversíveis sobre 0 incentivo tenderiam a compensar em determinada extensão os efeitos sobre o incentivo da existência de dívida arriscada já queo proprietário-administrador estaria compartilhando parte dos lucros associados a uma mudança da distribuição dos retornos com os detentores de títul os conversíveis. Desta forma, conjeturamos que os detentores potenciais de obrigações considerarão atrativo ter títulos conversíveis vinculados à dívida arriscada de firmas nas quais seja relativamente fácil mudar a distribuição dos resultados para expandir o limite inferior da distribuição visando a repassar a riqueza dos detentores de obrigações. Isso também seria atrativo para o proprietário-administrador, em função da redução dos custos deagência com os quais el e deveráarcar. Esse argumento também implica que faria pouca diferença se os títul os conversíveis fossem destacáveis (vendidos separadamente das obrigações), já que a sua mera existência reduziria os incentivos do administrador (ou dos acionistas) para aumentar o nível derisco da firma (e, portanto, aumentar a probabilidade de falência). Além disso, a inclusão de um privilégio de conversão de obrigações como dívida ou ações preferenciais em ações comuns também tenderiam a reduzir os efeitos de incentivo da existência dessas obrigações e, desta forma, reduzir os custos de agência associados a eles. A teoria prevê que esses fenômenos deveriam ser observados com mais freqüência nos casos em que os efeitos sobre 0 incentivo desses resgates fixos forem altos do que quando forem baixos.

\section{Monitoramento e o produto social dos analistas de títulos}

Uma das áreas para as quais uma análise posterior provavelmente levará a importantes insights se refere ao monitoramento. Atualmente temos pouco conhecimento que poderia ser englobado em uma "Teoria do Monitoramento" apesar de constituir um elemento fundamental da análise. Esperaríamos que instituições e indivíduos de posse de vantagem comparativa se especializem nas atividades de monitoramento. Um dos grupos que parecem exercer um importante papel nessas atividades é compostos de analistas de títulos empregados por investidores institucionais, corretoras e serviços de consultoria de investimentos, al ém de análises conduzidas por investidores individuais no curso normal de seu processo decisório referente aos investimentos.

Há muitas evidências indicando que os preços dos títulos incorporam de forma imparcial todas as informações disponíveis ao público e muito do que pode ser chamado de "informações privadas". ${ }^{69}$ Também há muitas evidências indicando que as atividades de análise de títulos de fundo mútuo e outros investidores institucionais são refletidos nos retornos do portfólio, i.e., elas não aumentam os retorno de portfólio ajustado ao risco ao longo de uma sel eção al eatória e simplista para uma estratégia de comprar e manter. ${ }^{70}$ Desta forma, al guns estudiosos foram tentados a concluir que os recursos gastos nesse tipo de atividade de pesquisa para identificar títul os sub- e sobrevalorizados representam uma perda social. Jensen (1974) argumenta que não é possível chegar a essa conclusão de forma inequívoca por haver uma grande elemento de consumo na demanda por esses serviços.

Além disso, a análise deste artigo pareceindicar que, na medida em que as atividades de análise de títulos reduzem os custos de agência associados à separação entre posse e controle, el as são, na verdade, social mente produtivas. Ademais, se isso se provar verdadeiro, esperamos que os principais benefícios da atividade de análise de títulos sejam refletidos no valor capitalizado superior dos direitos de propriedade para as empresas e não nos retornos de portfólio período-a-período do analista. 0 equilíbrio do setor de análise de títulos requer que os retornos privados das análise (i.e., os retornos do portfólio) devam ser pelo menos iguais aos custos privados dessa atividade, ${ }^{71}$ e isso não refletirá o produto social dessa atividade, que consistirá de uma maior produção e níveis mais al tos de valor de capital para os direitos de propriedade. Desta forma,o argumento implica que, se houver um volume não ótimo de análises de títulos sendo realizadas, esse volume é grande demais ${ }^{72}$ e não pequeno demais (já que os acionistas estariam dispostos a pagar diretamente para ter o monitoramento "ótimo" implementado) e não parecemos observar pagamentos dessa natureza.

\section{Especialização na utilização de capital de terceiros e capital próprio}

A nossa análise anterior dos custos de agência sugere pelo menos uma outra hipótese passível de teste: i.e., 
que nos setores em que os efeitos sobre o incentivo do capital próprio externo ou do capital de terceiros forem muito diferentes, esperaríamos ver uma especialização na utilização de um acordo de financiamento de baixo custo de agência. Em setores nos quais é relativamente fácil para os administradores reduzir o valor médio dos resultados do empreendimento por meio de furto direto, tratamento especial de clientes favorecidos, facilidade de consumo de lazer no trabalho, etc. (por exemplo, no setor de bares e restaurantes), esperaríamos ver a estrutura de propriedade de firmas caracterizada por relativamente baixo capital próprio externo (i.e., propriedade integral do capital próprio pelas equipes gerenciais) com praticamente todo capital externo obtido pela utilização de capital de terceiros.

A teoria prevê que o oposto seria verdadeiro onde os efeitos do capital de terceiros sobre o incentivo forem grandes em comparação com os efeitos do capital próprio sobre o incentivo. Firmas como conglomerados, nas quais seria fácil mudar as distribuição de resultado em prejuízo dos detentores de obrigações (por meio da alteração da política de aquisições ou de desinvestimento) deveriam ser caracterizadas por uma utilização rel ativamente menor de capital de terceiros. Por outro lado, em setores nos quais a liberdade da administração para assumir projetos mais arriscados é muito limitada (por exemplo, em indústrias regulamentadas, como as de serviços públicos), deveríamos observar uma utilização mais intensiva de financiamento com capital de terceiros.

A análise sugere que, além do papel significativamente bem compreendido da incerteza na determinação da qualidade das garantias, há pelo menos mais um outro elemento de grande importância - a capacidade do proprietário das garantias de mudar a distribuição dos resultados por meio da alteração do resultado médio ou da variância dos resultados. Um estudo de política de concessão de empréstimos por bancos deveria revelar que esses são importante aspectos das práticas contratuais observadas no setor.

\section{Aplicação da análise a uma grande empresa de posse pulverizada}

Apesar de acreditarmos que a estrutura esboçada acima seja aplicável a uma ampla variedade de empresas, a análise ainda está em um estado incompleto. Uma das suas maiores limitações é que, no presente momento, ainda não anal isamos a sua aplicação a uma grande empresa de posse pulverizada cujos administradores detêm pouca ou nenhuma participação no capital próprio. Acreditamos que a nossa abordagem possa ser aplicada a este caso, mas limitações de espaço impedem a discussão dessas questões neste artigo. Elas serão examinadas em detalhes e serão incluídas em um trabalho futuro.

\section{0 lado da oferta da questão dos mercados incompletos}

A análise deste artigo também é relevante para a questão do mercado incompleto abordada por Arrow (1964), Diamond (1967), Hakansson (1974a, b), Rubinstein (1974), Ross (1974), entre outros. Os problemas abordados nessa literatura são provenientes do fato de que, sempre que o conjunto disponível de direitos financeiros sobre os resultados em um mercado deixa de incluir o estado subjacente [veja Arrow (1964) e Debreu (1959)], a alocação resultante é Pareto-ineficiente. U m elemento perturbador dessa literatura gira em torno do fato de que geralmente se chega à conclusão de ineficiência sem uma atenção explícita na análise aos custos da criação de novos direitos ou de manutenção do conjunto expandido de mercados aos quais se recorre para gerar uma melhoria do bem-estar.

A demonstração de uma melhoria possível de bem-estar proveniente da expansão do conjunto de direitos por meio da inclusão de novos e básicos direitos contingentes ou opções pode ser considerada como uma análise das condições de demanda por novos mercados. Visto dessa forma, o que fal ta na literatura so bre a questão é a formulação de uma análise positiva da oferta dos mercados (ou da oferta de direitos contingentes). Em outras palavras, o que, no comportamento maximizador de indi víduos na economia, faz com que eles produzam e vendam direitos contingentes de vários tipos?

A análise apresentada neste artigo pode ser vista como um pequeno e primeiro passo na direção da formulação de uma análise da oferta de mercados, fundamentada no comportamento de maximizador visando ao interesse pessoal dos indivíduos. Demonstramos por que édo interesse de um empresário que pretende maximizar a riqueza criar e vender direitos como capital de terceiros e capital próprio. Além disso, como indicamos acima, aparentemente as extensões desses argumentos levarão a uma teoria da oferta de títulos conversíveis, títulos conversíveis em ações e ações preferenciais conversíveis em ordinárias. Não estamos sugerindo que a análise específica oferecida acima será suficiente para levar a uma teoria da oferta a ampla variedade de contratos ( tanto existentes quanto meramente potenciais) no mundo todo. Acreditamos, contudo, que a elaboração da questão da totalidade dos mercados em termos de unir as condições tanto da demanda quanto da oferta será muito proveitosa, em vez de pressupor impli- 
citamente que os novos direitos gerados de al guma fonte inesgotável (e sem custo) de criatividade sem a necessidade de ajuda ou apoio do esforço humano.

\section{CONCLUSÕES}

A empresa de capital aberto é uma impressionante invenção social. Milhões de pessoas voluntariamente confiam bilhões de dólares, francos, pesos, etc., de riqueza pessoal aos cuidados de administradores com base em um complexo conjunto de relações contratuais que delineiam os direitos das partes envolvidas. 0 crescimento da utilização da forma corporativa bem como o crescimento do valor de mercado de empresas sólidas sugere que, pelo menos atéo momento, credores e investidores de modo geral não têm se decepcionado com os resultados, apesar dos custos de agência inerentes à forma corporativa.

Os custos de agência são tão reais quanto quaisquer outros custos. 0 nível de custos de agência depende, entre outras coisas, de regulamentações e direito consuetudinário e da engenhosidade humana na elaboração de contratos. Tanto a legislação quanto a sofisticação de contratos relevantes à empresa moderna são produtos de um processo histórico no qual há grandes incentivos para que as pessoas minimizem os custos de agência. Ademais, há formas organizacionais alternativas disponíveis, além de oportunidades de inventar novas formas. Independentemente dos problemas, a corporação até 0 momento tem passado no teste do mercado contra alternativas potenciais.

\section{NOTAS}

U ma versão anterior deste artigo foi apresentada na Conference on Analysis and Ideology, Interlaken, Suíça, em junho de 1974, com o patrocínio do Center for Research in Government Policy and Business at the University of Rochester, Graduate School of Management. Somos gratos a F. Black, E. Fama, R. Ibbotson, W. Klein, M. Rozeff, R. Weil, O. Williamson, um leitor crítico anônimo e aos nossos colegas e membros da Finance Workshop da University of Rochester por seus comentários e crítica, mais especificamente a G. Benston, M. Canes, D. Henderson, K. Leffler, J. Long, C. Smith, R. Thompson, R. Watts e J. Zimmerman.

Artigo originalmente publicado por Michael $\mathrm{C}$. Jensen e William $\mathrm{H}$. Meckling, sob o título Theory of the firm: Managerial behavior, agency costs and ownership structure, no Journal of Financial Economics, v. 3, p. 305-360, 1976. Reproduzido em língua portuguesa com a autorização de CElsevier Science Publishers, 2008. www.elsevier.com
1. Não utilizamos o termo "estrutura de capital" porque esse termo em geral denota as quantidades relativas de obrigações, capital próprio, títulos conversíveis, crédito mercantil, etc., que representam o passivo exigível de uma firma. A nossa teoria implica a existência de uma outra importante dimensão a este problema - as quantias relativas de direitos de propriedade mantidas por insiders (administração) e outsiders (investidores sem função direta na administração da firma).

2. Revisões dessa literatura são fornecidas por Peterson (1965), Alchian (1965, 1968), Machlup (1967), Shubik (1970), Cyert e Hedrick (1972), Branch (1973), Preston (1975).

3. Veja Williamson (1964, 1970, 1975), Marris (1964), Baumol (1959), Penrose (1958) e Cyert e March (1963). Revisões meticulosas dessas e de outras contribuições foram feitas por Machlup (1961) e Alchian (1965).

Simon (1955) desenvolveu um modelo de escolha humana incorporando informações (busca) e custos computacionais que também apresentam importantes implicações para o comportamento dos administradores. Infelizmente, o trabal ho de Simon tem sido amplamente mal interpretado como uma negação do comportamento maximizador, e mal utilizado, especialmente na literatura sobre o marketing e ciência comportamental. A utilização do termo "satisficing", ou soluções satisfatórias, [Simon (1959)] sem dúvida contribuiu com essa confusão por sugerir a rejeição do comportamento maximizador e não da maximização sujeita aos custos das informações e da tomada de decisões.

4. Veja Meckling (1976) para uma discussão sobre a importância fundamental da premissa de um comportamento maximizador, avaliativo e engenhoso por parte dos indivíduos no desenvolvimento da teoria. Klein (1976) assume uma abordagem similar à que utilizamos neste artigo em sua revisão da teoria da firma e seus aspectos legais.

5. Veja Coase $(1937,1959,1960)$, Alchian $(1965,1968)$, Alchian eKessel (1962), Demsetz (1967), Alchian e Demsetz (1972), Monsen e Downs (1965), Silver e Auster (1969) e McManus (1975).

6. Direitos de propriedade são, naturalmente, direitos humanos, i.e., direitos possuídos por seres humanos. A introdução dessa distinção totalmente descabida entre direitos de propriedade e direitos humanos em muitas discussões sobre políticas é sem dúvida um dos maiores disparates semânticos de todos os tempos.

7. Cf. Berhold (1971), Ross (1973, 1974a), Wilson (1968, 1969) e Heckerman (1975).

8. Dadas as atividades ótimas de monitoramento e concessão de garantias contratuais por parte do principal e do agente.

9. Neste artigo, o termo "monitoramento" inclui mais do que a simples mensuração ou observação do comportamento do agente. 0 termo, aqui, inclui os esforços por parte do principal de "controlar" o comportamento do agente por meio de restrições orçamentárias, políticas de remuneração, regras operacionais, etc.

10. Como demonstraremos mais adiante, a existência de custos positivos de monitoramento e de concessão de garantias contratuais resultará no administrador de uma empresa de posse do controle sobre al guns recursos que ele poderá alocar (dentro de certas limitações) para satisfazer a suas próprias preferências. Contudo, na medida em que ele deve obter a cooperação dos outros para desempenhar suas funções (como vice-presidentes 
de divisão) e na medida em que ele não tem como controlar perfeitamente e sem custos o comportamento dos outros, eles poderão se apropriar de parte desses recursos para os seus próprios fins. Em resumo, custos de agência são gerados em todos os níveis da organização. Infelizmente, a análise dessas questões organizacionais mais gerais chega a ser até mais difícil do que a análise da questão de "posse e controle", já que a natureza das obrigações contratuais e direitos das partes é muito mais variada e em geral não tão bem especificada em cláusulas contratuais explícitas. Contudo, não podemos negar sua existência e acreditamos que as extensões da nossa análise nessas direções são promissoras no sentido de gerar insights e, possivelmente, uma teoria razoável da organização.

11. Eles definem a firma capital ista clássica como uma organização contratual de inputs na qual há: "(a) uma produção coletiva de inputs; (b) vários proprietários dos inputs; (c) uma parte comum a todos os contratos dos inputs conjuntos; (d) quem detém os direitos de renegociar o contrato de qualquer input independentemente dos contratos com outros proprietários de inputs; (e) quem detém os direitos residuais; e (f) quem tem o direito de vender o seu status residual contratual".

12. Utilizamos o termo "ficção legal" para denotar o constructo artificial de acordo com a lei que permite que al gumas organizações sejam tratadas como indivíduos.

13. Por exemplo, costumamos pensar sobre um produto como algo que deixa a firma no momento em que é vendido, mas implícita ou explicitamente, essas vendas em geral carregam consigo contratos contínuos entre a firma e o comprador. Se o produto não apresentar o desempenho esperado, o comprador normalmente pode exercer o seu direito de ser satisfeito. Uma evidência concreta da existência desses contratos implícitos éa prática que ocasional mente observamos da cláusula contratual específica que afirma que "todas as vendas são finais".

14. Esta visão da firma é um indicativo do importante papel que o sistema legal e a lei exercem nas organizações sociais, em especial, a organização da atividade econômica. Instrumentos legais definem limites aos riscos dos contratos nos quais indivíduos e organizações podem entrar sem arriscar uma acusação criminal. Os poderes políticos do estado são disponíveis e utilizados para garantir o cumprimento dos contratos ou para pôr em execução as cobranças de danos causados por desempenho insatisfatório. Os tribunais decidem judicialmente conflitos entre as partes do contrato e estabelecem precedentes que compõem o direito consuetudinário. Todas essas atividades governamentais afetam tanto os tipos de contratos executados quanto a extensão na qual os contratos são confiáveis. Isso, por sua vez, determina o nível de utilidade, produtividade, lucratividade e viabilidade das várias formas de organização. Além disso, novas leis, além de decisões judiciais costumam ter o poder de alterar, ex post, os direitos das partes envolvidas no contrato, o que efetivamente fazem e podem e de fato atuam como um veículo de redistribuição de riqueza. Uma análise de al gumas implicações desses fatos foi apresentada em Jensen e M eckling (1976) e não as abordaremos aqui.

15. Para a utilização no consumo, para a diversificação de sua riqueza ou, ainda mais importante, para o financiamento de projetos "lucrativos" que ele de outra maneira não teria como financiar com a sua riqueza pessoal. Lidamos com essas questões mais adiante, após termos desenvolvido al gumas das ferramentas analíticas básicas necessárias para a sua solução.

16. Como as instalações do escritório, ar-condicionado, espessura dos carpetes, cordialidade nos relacionamentos entre empregados, etc.
17. Mais uma vez presumimos que, para qualquer dado valor de mercado desses custos, F, para a firma, a alocação ao longo do tempo e entre alternativas de distribuição de probabilidade é tal que a utilidade esperada atual do administrador está no seu máximo.

18. N este estágio, quando consideramos uma firma administrada por seu proprietário integral, a noção de "contrato salarial" consigo mesmo não se aplica. Entretanto, o caso de uma firma administrada por seu proprietário integral não passa de um recurso argumentativo que utilizamos de passagem para ilustrar uma série de pontos da análise e pedimos paciência ao leitor enquanto esboçamos a estrutura para o caso de propriedade parcial, mais interessante, ao qual um contrato como esse se aplica.

19. A função de utilidade do administrador é, na verdade, definida em termos da riqueza e da seqüência temporal futura dos vetores das quantidades de benefícios não pecuniários, $X_{\mathrm{t}}$. Apesar de o cenário para este problema ser relativamente distinto, Fama (1970b, 1972) analisa as condições nas quais essas preferências podem ser representadas como uma função de utilidade derivada definida como uma função do valor monetário dos gastos (na nossa notação, F) desses bens dependendo dos preços dos bens. Uma função de utilidade como essa incorpora a otimização que se desenrola em segundo plano, que define $0 \hat{X}$, discutido anteriormente, para um dado $F$. No caso mais geral em que permitimos uma série temporal do consumo, $\hat{X}_{t^{\prime}}$ a otimização ocorre ao longo do tempo e em relação aos componentes de $X_{t^{\prime}}$ para um $F$ fixo.

20. Isso exclui, por exemplo: (a) o caso no qual se permite que o administrador gaste recursos corporativos no que desejar e, neste caso, F seria um substituto perfeito para a riqueza, ou (b) o caso no qual ele pode "roubar" caixa (ou outros ativos comercializados) com retornos constantes de escala - neste caso, as curvas de indiferença seriam linhas retas com inclinação determinada pela comissão de proteção.

21. $O$ ponto $D$ define os benefícios adicionais no pacote de remuneração ótimo já que o valor para o administrador dos benefícios adicionais, $\mathrm{F}^{*}$, é maior do que o custo de proporcioná-los, como fica claro pelo fato de que $U_{2}$ é mais inclinado para a esquerda de $D$ do que a restrição orçamentária com inclinação igual a -1 .

O fato de D ser, de fato, um pacote de remuneração ótimo poder ser facilmente observado nesta situação, já que, se as condições da venda ao agora proprietário especificarem que o gerente não receberia benefícios adicionais após a venda, ele exigiria um pagamento igual $a V_{3}$ pelo sacrifício de seus direitos, $V^{*}$, e benefícios adicionais de $\mathrm{F}^{*}$ (com valor total para ele de $\mathrm{V}_{3}$ - $V^{*}$ ). Mas, se $F=0$, o valor para a firma é de apenas $\bar{V}$. Desta forma, se os custos de monitoramento fossem zero, a venda ocorreria em $\mathrm{V} *$ com cláusula contratual para um pacote de remuneração que incluísse benefícios adicionais de $\mathrm{F} *$ para 0 administrador.

Essa discussão parece indicar a existência de dois val ores pra a "firma", $V_{3}$ e $V^{*}$. Este não é o caso se percebermos que $V^{*}$ é o valor do direito de ser o requerente residual dos fluxos de caixa da firma $\mathrm{eV}_{3}-\mathrm{V} *$ é o valor dos direitos do administrador, i.e., o direito de tomar as decisões operacionais, que incluem o acesso a $\mathrm{F}^{*}$. Há pelo menos um outro direito que apresenta um valor que não tem nenhum papel formal na análise até o momento o valor do direito pelo controle. Por "direito pelo controle" nos referimos ao direito de contratar e demitir o administrador, e deixamos essa questão para um trabalho posterior.

22. A distância $V *-V$ ' é uma medida do que definiremos como os custos brutos de agência. A distância $V_{3}-V_{4}$ é uma medida do que chamaremos 


\section{MICHAEL C. JENSEN •WILLIAM H. MECKLING}

de custos líquidos de agência e é esta medida dos custos de agência que será minimizada pelo administrador no caso geral no qual permitimos a alteração do investimento.

23. I* é o nível de investimento no ótimo de Pareto para a maximização do valor, que resulta da análise tradicional da decisão de investimento corporativo se a firma operar em mercados de produto e capital perfeitamente competitivos e se os problemas do custo de agência discutidos aqui forem ignorados. Veja Debreu (1895, cap. 7), Jensen e Long (1972), Merton e Subrahmanyam (1974), Hirshleifer $(1958,1970)$ e Fama e Miller (1972).

24. Cada ponto de equilíbrio, como o ponto $E$, é caracterizado por $\left(\hat{\alpha}, \hat{F}, \hat{W}_{T}\right)$, onde $\hat{W}_{T}$ é a is riqueza do empresário investimento-financiamento. Esse equilíbrio deve satisfazer a cada uma das quatro condições a seguir:

$$
\hat{W}_{T}+\mathrm{F}=\bar{V}(\mathrm{I})+\mathrm{W}-\mathrm{I}=\bar{V}(\mathrm{I})-\mathrm{K},
$$

onde $\mathrm{K} \equiv \mathrm{I}$ - W éa quantia de financiamento externo necessária para fazer o investimento I. Se essa condição não for satisfeita, há uma transferência não compensada de riqueza (em uma ou em outra direção) entre o empresário e os compradores do capital próprio externo.

$$
\mathrm{U}_{\mathrm{F}}\left(\hat{W}_{T}+\hat{F}\right) / \mathrm{U}_{\mathrm{W}_{T}}\left(\hat{W}_{T}+\hat{F}\right)=\hat{\alpha},
$$

onde $U$ é a função de utilidade do empresário em relação à riqueza e às vantagens ou mordomias, $U_{F}$ e $U_{W_{T}}$ são utilidades marginais e $\hat{\alpha}$ é a participação do administrador na firma.

$$
(1-\hat{\alpha}) \bigvee(I)=(1-\hat{\alpha})[\bar{V}(I)-\hat{F}] \geq K,
$$

que afirma que os fundos recebidos dos outsiders são pelo menos iguais a K, o financiamento externo mínimo requerido.

(4) Entre todos os pontos $\left(\hat{\alpha}, \hat{F}, \hat{W}_{T}\right)$ que satisfazem às condições (1) a (3), $(\alpha, \mathrm{F}, \mathrm{WT})$ oferece ao administrador a mais alta utilidade. Isso implica que $\left(\hat{\alpha}, \hat{F}, \hat{W}_{T}\right)$ satisfazem a condição (3) como uma igualdade.

25. Prova. Observe que a inclinação da trajetória de expansão (ou lugar geométrico dos pontos de equilíbrio) em qualquer ponto é $(\Delta \mathrm{V}-\Delta \mathrm{l}) / \Delta \mathrm{F}$ e que o nível ótimo de investimento deve ser igual à inclinação da curva de indiferença do administrador entre a riqueza e o valor de mercado dos benefícios adicionais, F. Além disso, na ausência de monitoramento, a inclinação da curva de indiferença, $\Delta \mathrm{W} / \Delta \mathrm{F}$ no ponto de equilíbrio, $\mathrm{D}$, deve ser igual a $-\alpha$ '. Desta forma,

$(\Delta \mathrm{V}-\Delta \mathrm{l}) / \Delta \mathrm{F}=-\alpha^{\prime}$

é a condição para a escala ótima de investimento, o que implica que a condição (1) se aplica a pequenas variações do nível ótimo de investimento, I'.

26. Como as curvas de indiferença do administrador apresentam inclinação negativa, sabemos que a escala ótima da firma, o ponto $D$, ocorrerá na área onde a trajetória de expansão tem inclinação negativa, i.e., o valor de mercado da firma estará em queda e os custos brutos de agência, $A$, estarão aumentando e, desta forma, o administrador não os minimizará tomando a decisão de investimento (apesar de que ele os minimizará para qual quer dado nível de investimento). Contudo, definimos o custo líquido de agência como 0 equivalente em unidades monetárias da perda de bem- estar por parte do administrador porque a relação de agência avaliada em $F=0$ (a distância vertical entre as intersecções no eixo y das duas curvas de indiferença que passam pelos pontos C e D). A solução ótima, I', de fato satisfaz à condição de que os custos líquidos de agência são minimizados. Mas isso somente leva a uma confirmação do pressuposto de que 0 administrador maximiza o seu bem-estar.

Finalmente, é possível, para a solução, que o ponto D seja uma solução de canto e, neste caso, o valor da firma não estará em queda. Essa solução de canto pode ocorrer, por exemplo, se a taxa marginal de substituição do administrador entre $F$ e a riqueza caia a zero com velocidade suficiente à medida que percorremos a trajetória de expansão para cima, ou se os projetos de investimento sejam "suficientemente" lucrativos. N estes casos, a trajetória de expansão terá um vértice no valor máximo da restrição orçamentária com intersecção $\bar{V}\left(I^{*}\right)$ - I*, e o nível de investimento será igual ao ótimo idealizado, $I^{*}$. Contudo, o valor de mercado dos direitos residuais será menor que $V^{*}$ porque 0 consumo de vantagens ou mordomias por parte do administrador será maior que F*, o nível de custo de agência zero.

27. 0 leitor atento notará que o ponto $\mathrm{C}$ será o ponto de equilíbrio somente se 0 contrato entre 0 administrador e os detentores do capital próprio externo especificarem claramente que não têm o direito de monitorar ou restringir o consumo de vantagens ou mordomias por parte do administrador a uma quantia não inferior a F". Se o contrato for de alguma forma vago no que se refere a esses direitos, surge uma outra fonte de custos de agência, simétrica ao nosso problema original. Se isso fosse possível, os detentores do capital próprio externo monitorariam o administrador até o ponto no qual o valor líquido da participação dos investidores, $(1-\alpha)$ $V-M$, seja maximizado, o que ocorrerá quando $(\partial \mathrm{V} / \partial \mathrm{M})(1-\alpha)-1=0$, o que estaria em algum ponto entre os pontos $C$ e E na Figura 3.0 ponto E indica o ponto no qual o valor líquido dos custos de monitoramento da firma está no seu máximo, i.e. onde $\partial \mathrm{V} / \partial \mathrm{M}-1=0$. M as 0 administrador estaria em uma situação pior do que na solução de monitoramento zero se 0 ponto no qual $(1-\alpha) V-M$, no seu máximo, estiver à esquerda da intersecção entre $B C E$ e a curva de indiferença $U_{3}$ que passa pelo ponto $B$ (o que indica o nível zero de monitoramento do bem-estar). Desta forma, se 0 administrador não puder fazer com que o contrato seja preciso e claro o suficiente para empurrar o equilíbrio para a direita da intersecção da curva $B C E$ com curva de indiferença $\mathrm{U}_{3}$, ele não firmará nenhum contrato que permita o monitoramento.

28. Se pudermos estabelecer a existência de um conjunto viável de acordos institucionais alternativos que resultariam em benefícios líquidos a partir da redução desses custos, seria possível concluir que a relação de agência promovida pela empresa não está no ótimo de Pareto. N este caso, contudo, seríamos deixados com o problema de explicar por que esses acordos institucionais alternativos não substituíram a forma corporativa da organização.

29. Os custos de monitoramento e de concessão de garantias contratuais diferirão de firma à outra dependendo de fatores como a complexidade inerente e a dispersão geográfica das operações, da atratividade das mordomias disponíveis na firma, etc.

30. “Onde há numerosos concorrentes e a entrada éfácil, saídas persistentes de comportamento maximizador de lucro inexoravel mente leva à extinção. A seleção natural econômica domina o cenário. Nessas circunstâncias, o comportamento das unidades individuais que constituem o lado da oferta do mercado de produto é essencialmente rotineira e desinteressante e os economistas podem prever o comportamento do setor com confiança sem se ater explicitamente ao comportamento dessas unidades individuais. 


\section{RAE-CLÁSSICOS TEORIA DA FIRMA: COMPORTAMENTO DOS ADMINISTRADORES, CUSTOS DE AGÊNCIA E ESTRUTURA DE PROPRIEDADE}

Q uando as condições da concorrência são afrouxadas, contudo, o conjunto de oportunidades da firma é expandido. N este caso, o comportamento da firma como uma unidade operacional independente é de interesse distinto. Tanto para fins de interpretação do comportamento específico na firma como para prever as reações do setor como um todo, pode ser necessário identificar os fatores que influenciam as escolhas da firma dentro desse conjunto expandido de oportunidades e incorporar essas escolhas em um modelo formal" (WILLIAMSOM, 1964, p. 2).

31. Presumindo a ausência de benefícios fiscais especiais para a propriedade ou de utilidade da propriedade além da resultante dos efeitos diretos da riqueza sobre a propriedade, como pode se aplicar para times esportivos profissionais, estábulos de cavalos de corrida, firmas que levam 0 nome da família, etc.

32. Marris (1964, pp. 7-9) é a exceção, apesar de argumentar que há um 'ponto de alavancagem máximo' além do qual as possibilidades de 'insolvência' são, em algum sentido indefinido, altas demais.

33. Por "responsabilidade limitada" nos referimos às mesmas condições que se aplicam às ações ordinárias. Empréstimos subordinados ou ações preferenciais podem ser agregados, levando a provisões de passivo exigível; i.e., os ativos da empresa foram insuficientes em al gum momento para liquidar todas as dívidas anteriores (como crédito mercantil, salários acumulados, dívida principal, etc.) e, se os recursos pessoais dos detentores de "capital próprio" também forem insuficientes para cobrir essas dívidas, os detentores dessa "dívida" seriam sujeitos a tributações além do valor nominal da dívida (tributações cujo montante pode ser limitado ou ilimitado).

34. Alchian-Demsetz (1972, p. 709) argumentam que é possível explicar a existência tanto de obrigações quanto de ações na estrutura de propriedade das firmas como uma conseqüência de diferentes expectativas relativas aos resultados da firma. Eles argumentam que as obrigações são criadas e vendidas a "pessimistas" e que as ações com direitos residuais sem limite superior são vendidas a "otimistas".

Se os mercados de capital forem perfeitos, sem tributações ou custos de transações, e os investidores individuais puderem realizar seus direitos sobre a distribuição de resultados nos mesmos termos que as firmas, essas ações por parte das firmas não podem afetar seus valores. A razão para isso é simples. Suponha que esses "pessimistas" de fato existam e, mesmo assim, a firma emita somente direitos sobre o capital próprio. A demanda por esses direitos sobre o capital próprio refletiria o fato de que o comprador individual poderia, por conta própria, emitir "obrigações" com direitos limitados e antecipados sobre a distribuição dos resultados do capital próprio que sejam exatamente iguais aos que poderiam ser emitidas pela firma. De forma similar, os investidores poderiam facilmente "desalavancar" qualquer posição pela simples compra de direitos proporcionais tanto de obrigações quanto de ações de uma firma alavancada. Desta forma, uma firma alavancada não poderia vender a um preço diferente da de uma empresa "desalavancada" simplesmente devido à existência dessas diferentes expectativas. Veja Fama and Miller (1972, cap. 4) para uma excelente exposição dessas questões.

35. As empresas de fato usaram os dois recursos antes da instauração do imposto de renda corporativo nos Estados Unidos e os dividendos preferenciais, nunca, com pequenas exceções, puderam ser deduzidos do imposto de renda.

36. Veja Kraus e Litzenberger (1972) e Lloyd-Davies (1975).
37. E, se houver licitação competitiva pela firma por parte de proprietário e administradores potenciais, o proprietário ausente se beneficiará do valor capitalizado desses custos de agência.

38. A variedade de ações que as firmas podem emitir é muito mais diversificada do que é sugerida pela nossa classificação bilateral - fixas versus residuais. Há a possibilidade de emitir títulos conversíveis em ações, certificados de reserva de domínio, debêntures, obrigações de receita, títulos conversíveis, etc. Diferentes obrigações podem conter diferentes provisões de subordinação, no que se refere a ativos e juros. Elas podem ou não ser resgatadas antes do vencimento. Ações preferenciais podem ser "preferenciais" em diferentes dimensões e conter uma variedade de condições de subordinação. Em resumo, podemos imaginar firmas emitindo ações de acordo com uma variedade literal mente infinita de estados do mundo, como as analisadas na literatura sobre os model os de tempo-estado-preferência de Arrow (1964), Debreu (1959) e Hirshleifer (1970).

39. Uma analogia adequada para isso é a forma como se joga pôquer com dinheiro tomado de empréstimo a uma taxa de juros fixa, com o próprio limitado a riscos muito baixos. Fama e Miller (1972, p. 179-180) também analisam e fornecem vários exemplos de uma decisão de investimento ilustrando a incoerência potencial entre os interesses dos detentores de obrigações e os dos acionistas.

40. As questões de diversificação de portfólio que devem ser consideradas pelo proprietário-administrador são analisadas na The Seção 5, mais adiante.

41. Veja Smith (1976) para uma revisão dessa literatura sobre precificação de opções e suas aplicações e Galai e Masulis (1976), que aplicam o modelo de precificação de opções a fusões e decisões de investimento corporativo.

42. Apesar de utilizarmos o modelo de precificação de opções acima para motivar a discussão e proporcionar uma compreensão intuitiva dos incentivos que devem ser levados em consideração pelos detentores de capital próprio, as soluções de precificação de opções de Black e Scholes (1973) não se aplicam quando os efeitos do incentivo fazem com que $V$ seja uma função da razão entre capital de terceiros e capital próprio, como ocorre em geral e neste exemplo. Long (1974) chama a atenção a essa dificuldade no que se refere à utilidade do model o no contexto de subsídios fiscais sobre os juros e o custo de falência. Os resultados de Merton (1974) e Galai e Masulis (1976) devem ser interpretados com atenção, já que as soluções são estritamente incorretas no de subsídios e/ou custos de agência.

43. 0 exemplo numérico de Fama e Miller (1972, p. 179-180) é uma representação similar a este caso em um modelo de dois períodos-estados. Contudo, eles prosseguem com a seguinte afirmação na p. 180:

'Do ponto de vista prático, contudo, situações de conflito potencial entre detentores de obrigações e acionistas na aplicação da regra do valor de mercado são, provavelmente, irrelevantes. Em geral, oportunidades de investimento que aumentam o valor de mercado de uma firma em uma quantia maior do que seu custo aumentam, ao mesmo tempo, o valor das ações da empresa e fortalecem a capacidade futura da firma de satisfazer seu compromisso com as obrigações atuais.'

A primeira questão relativa à importância do conflito de interesses entre detentores de obrigações e acionistas é uma questão empírica e a última afirmação é incompleta - em algumas circunstâncias, os detentores de capital próprio poderiam se beneficiar de projeto cujo efeito líquido é a 


\section{MICHAEL C. JENSEN •WILLIAM H. MECKLING}

redução do valor total da firma como foi ilustrado por eles e por nós. A questão não pode ser negligenciada tão facilmente.

44. Myers (1975) salienta um outro grande efeito sobre o incentivo para as decisões administrativas da existência de capital de terceiros que não ocorre no nosso mundo simplificado de uma única decisão. Ele demonstra que, se a firma tem a opção de assumir oportunidades de investimento futuro, a existência de capital de terceiros com vencimento após as opções serem feitas fará com que a firma (utilizando uma regra de investimento maximizadora de capital próprio se recuse a assumir alguns projetos de outra forma lucrativos, já que esses projetos beneficiariam somente os detentores de obrigações e não os detentores de capital próprio. Isso fará com que (na ausência de subsídios fiscais ao capital de terceiros) o valor da firma seja reduzido. Desta forma (apesar de ele não utilizar o termo), esses efeitos sobre 0 incentivo também contribuem para os custos de agência do capital de terceiro de maneira perfeitamente compatível com os exemplos discutidos no texto.

45. Black eScholes (1973) discutem formas nas quais as políticas de financiamento futuro e dividendos podem redistribuir a riqueza entre diferentes classes de detentores de direitos da firma.

46. Black, Miller e Posner (1974) discutem muitas dessas questões com referência específica à regulamentação do governo para empresas de holding bancária.

47. Em outras palavras, esses custos serão levados em consideração na determinação do rendimento na data de vencimento. Para uma análise dos efeitos dos custos de garantir o pagamento das taxas nominais de juros no pequeno mercado de empréstimos ao consumidor, veja Benston (1977).

48. Para ilustrar o fato de que, em al gumas circunstâncias, compensa para 0 administrador incorrer em custos de "concessão de garantias contratuais" para assegurar aos detentores de obrigações que ele não se desviará do comportamento prometido, vamos supor que, para um gasto de $\$ b$ dos recursos da firma, ele possa garantir que o projeto 1 será escolhido. Se ele gastar esses recursos e escolher o projeto 1,0 valor da firma será $V_{1}-b$ , claramente, na condição de que $\left(V_{1}-b\right)>V_{2}$, ou, por outro lado, que $\left(V_{1}-V_{2}\right)>b$, se beneficiará da situação, já que a sua riqueza será igual ao valor da firma menos o investimento necessário, I (que supomos, para fins de simplificação, ser o mesmo para os dois projetos).

Por outro lado, para provar que o proprietário-administrador prefere a solução de mais baixo custo, presumimos que ele possa elaborar uma disposição contratual para a emissão das obrigações que permitirá aos detentores das obrigações impedi-lo de escolher o projeto 2, se eles incorrerem em custos de monitoramento de $\$ m$, onde $m<b$. Se ele fizer isso, a sua riqueza será mais alta na quantia $b$ - $m$. Para verificar isso, observe que, se 0 mercado de obrigações for competitivo e fizer estimativas imparciais, detentores potenciais de obrigações serão indiferentes entre:

(i) um direito $X^{*}$ sem disposições contratuais (e sem garantias por parte da administração) ao preço $B_{2^{\prime}}$

(ii) um direito $X^{*}$ sem disposições contratuais (e garantias por parte da administração, por meio de despesas com a concessão de garantias contratuais de $\$ b$, incorridas pela empresa, para que o projeto 1 seja escolhido) ao preço $B_{1}$, e

(iii) um direito $X^{*}$ com disposição contratual e a oportunidade de gastar $\mathrm{m}$ em monitoramento (para garantir que o projetol será escolhido) ao preço $B_{1}-m$
Os detentores de obrigações perceberão que (i) representa, de fato, um direito sobre o projeto 2 e que (ii) e (iii) representam um direito sobre o projeto 1 e permanecem, desta forma, indiferentes entre as três opções aos preços especificados. 0 proprietário-administrador, contudo, não será indiferente entre incorrer diretamente com os custos de concessão de garantias contratuais, b, ou incluir as disposições contratuais no contrato das obrigações, permitindo que os detentores das obrigações gastem $\mathrm{m}$ para garantir que ele escolha o projeto 1. A riqueza do proprietárioadministrador nos dois casos será dada pelo valor de seu capital próprio mais os lucros das obrigações emitidas menos o investimento necessário e, se $m<b<V_{1}-V_{2}$, a sua riqueza após o investimento-financiamento, $W$, para as três opçỗes será tal que $W_{i}<W_{i i}<W_{i i i}$. Desta forma, como isso aumentaria a sua riqueza, ele voluntariamente incluiria a disposição contratual no acordo das obrigações e permitiria que os detentores das obrigações o monitorem.

49. Mencionamos, sem detalhar o problema, que, de maneira similar ao caso no qual os detentores de capital próprio externo podem monitorar o proprietário-administrador, a relação de agência entre os detentores das obrigações e os acionistas apresenta uma simetria se os direitos dos detentores das obrigações de limitar as ações do administradores não forem perfeitamente esclarecidos em contrato. Suponha que os detentores das obrigações, ao gastar quantias suficientemente altas de recursos, pudessem forçar a administração a executar ações que transfeririam a riqueza do detentor do capital próprio aos detentores das obrigações (assumindo projeto suficientemente menos arriscados). Seria fácil imaginar situações nas quais essas ações favoreceriam os detentores das obrigações, prejudicariam os detentores do capital próprio e, de fato, reduziriam o valor total da firma. Devido à natureza do contrato de dívida, o proprietário-administrador original poderia maximizar a sua riqueza em uma situação como essa liquidando o capital próprio e mantendo as obrigações na qualidade de "proprietário". Presumindo essa natureza do contrato de obrigações, essa situação pode consistir em uma solução ineficiente, já que os custos de agência totais (i.e., a soma da perda de valor e monitoramento) poderiam facilmente ser superiores em relação à solução alternativa. Contudo, se 0 proprietário-administrador tivesse como limitar os direitos dos detentores das obrigações (talvez por meio da inclusão de uma cláusula contratual com restrições expressas a todos os direitos não especificamente concedidos ao detentores das obrigações para o detentor do capital próprio), ele consideraria de seu interesse firmar o acordo contratual eficiente, já que, ao minimizar os custos de agência, ele estaria maximizando a sua própria riqueza. Essas questões envolvem a natureza fundamental dos contratos e, por enquanto, simplesmente presumimos que os direitos dos "detentores das obrigações" são estritamente limitados e claros e que todos os direitos não especificamente concedidos a eles são reservados aos "acionistas", uma situação que descreve acordos institucionais reais. Isso nos permite evitar os efeitos sobre o incentivo associados a "detentores das obrigações" potencialmente explorando os "acionistas".

50. Se a firma tivesse como vender os ativos para satisfazer uma obrigação de dívida atual, a falência ocorreria quando o valor de mercado total dos fluxos de caixa futuros esperados da empresa for menor do que 0 valor de um pagamento atual de uma obrigação de dívida. Contudo, muitas disposições contratuais não permitem a venda de ativos para atender as obrigações de dívida.

51. Fomos informados de que, apesar de isso ser verdadeiro em princípio, o comportamento real dos tribunais com freqüência parece envolver al gum acordo para os detentores de ações ordinárias mesmo se os ativos da empresa não forem suficientes para cobrir os direitos dos credores. 
52. Se, diante da falência, os detentores de obrigações tiverem o direito de demitir o administrador, a administração terá alguns incentivos para evitar ações que aumento a probabilidade desse evento (mesmo se isso for do interesse dos detentores do capital próprio) se eles (a administração) estiverem recebendo rendimentos ou se tiverem capital humano especializado na empresa ou se estiverem diante de grandes ajustes de custos para encontrar novos empregos. U ma análise detalhada dessa questão envolve o valor dos direitos pelo controle (os direito de contratar e demitir o administrador), e deixamos essa questão para um trabalho posterior.

53. Kraus e Litzenberger (1972) e Davies (1975) demonstram que o valor total da firma será reduzido no montante desses custos.

54. Inclui apenas pagamentos a todas as partes por honorários legais, serviços profissionais, despesas fiduciárias e taxas de registro. Sem incluir os custos pelo tempo da administração ou alterações dos fluxos de caixa devido a mudanças das funções de demanda ou custo da firma discutidos mais adiante.

55. 0 que, a propósito, existe apenas quando a dívida tem al guma probabilidade de inadimplência.

56. A nossa teoria é capaz de explicar por que, na ausência de subsídios fiscais par aos pagamentos de juros, seria possível esperar encontrar firmas utilizando tanto capital de terceiros quanto ações preferenciais - um problema que há muito tem intrigado pelo menos um dos autores. Se as ações preferenciais apresentarem todas as características do capital de terceiros, com exceção do fato de que os detentores não têm como abrir falência para a firma no caso de inadimplência dos dividendos preferenciais, os custos de agência associados à emissão das ações preferenciais será menor do que os custos associados com o capital de terceiro na medida do valor presente dos custos de falência.

Contudo, esses custos de agência mais baixos para as ações preferenciais só existem em uma determinada faixa, se, à medida que a quantidade dessas ações aumentar os efeitos sobre o incentivo causados por sua existência impõem reduções de valor que são maiores do que a reduções causadas pelo capital de terceiros (incluindo os custos de falência do capital de terceiros). Há duas razões para isso. Em primeiro lugar, os direitos do detentor do capital próprio podem ser eliminados pelos detentores do capital de terceiros no caso de falência e, em segundo lugar, os detentores do capital de terceiros têm o direito de demitir a administração no caso de falência. Ambas essas razões tenderão a se tornar mais importante como uma vantagem à emissão do capital de terceiros à medida que comparamos situações com grandes quantidades de ações preferenciais com situações equivalentes com grandes quantias de capital de terceiros, já que elas tenderão a reduzir os efeitos sobre os incentivos de grandes quantidades de ações preferenciais.

57. Uma condição adicional também precisa se aplicar para justificar a incidência dos custos associados à utilização do capital de terceiros ou do capital próprio externo na nossa firma. Se houver outros indivíduos na economia com quantias suficientemente grandes de capital pessoal para financiar toda a firma, o nosso proprietário com restrições de capital pode realizar todo o valor de capital de seus projetos atuais e potenciais e evitar os custos de agência simplesmente vendendo a firma (i.e., o direitos e assumir esses projeto) a um desses indivíduos. Desta forma, ele evitará as perdas de riqueza associadas aos custos de agência causadas pela venda do capital de terceiros ou do capital próprio externo. $\mathrm{Na}$ ausência de indivíduos com essas características, compensará a ele (e à sociedade) obter o capital adicional no mercado de dívidas. Isso implica, a propósito, queé em alguma extensão enganoso pensar no proprietário-administrador como a pessoa que incorre com os custos de agência. Seria possível argumentar que é o projeto que arca com os custos, já que, se não for suficientemente lucrativo cobrir todos os custos (incluindo os custos de agência), o projeto não será assumido. Continuaremos imaginar o proprietário-administrador arcando com esses custos para enfatizar o ponto mais preciso e importante de que ele tem o incentivo de reduzi-los já que, caso o fizer, a sua riqueza aumentará.

58. Continuaremos a ignorar, por enquanto, o fator complicador adicional envolvido nas decisões de portfólio por parte do proprietário e a aceitação implícita do risco potencialmente diversificável assumido por esses proprietários integrais neste exemplo.

59. Continuaremos ignorando instrumentos como títulos conversíveis em ações e títulos conversíveis.

60. Observe, contudo, que, mesmo quando os outsiders não são proprietários denenhum capital próprio, o acionista-administrador ainda tem alguns incentivos para se envolver em atividades que lhe renderão benefícios não pecuniários mas reduzirão o valor da firma em um quantia maior do que a sua estimativa de seus benefícios pessoais, se houver qualquer dívida arriscada em aberto. Q uaisquer dessas ações, por parte do acionista-administrador, que reduzem o valor da empresa, $V$, tendem a reduzir o valor das obrigações além do capital próprio. Apesar de, em geral, o modelo de precificação de opções não se aplicar exatamente ao problema de estimativa do capital de terceiros e do capital próprio da firma, ele pode ser útil para se chegar a alguns insights qualitativos em questões como estas. No modelo de precificação de opções, $\partial \mathrm{S} / \partial \mathrm{V}$ indica a taxa na qual o valor da ação muda por variação por unidade monetária da firma (e, de forma similar, para $\partial B / \partial V$ ). Ambos esses termos são menores que 1 [cf. Black e Scholes (1973)]. Desta forma, qualquer ação por parte do administrador que reduza o valor da firma, $V$, tende a reduzir o valor tanto das ações quanto das obrigações e, quanto maior for a razão total entre capital de terceiros e capital próprio, menor será o impacto de qualquer dada variação de V sobre o capital próprio e, desta forma, menor será o custo do administrador de consumir benefícios não pecuniários.

61. Isso ocorre, é claro, não na intersecção entre $A_{S_{0}}(E)$ e $A_{B}(E)$, mas no ponto em que 0 valor absoluto das inclinações das funções são iguais, i.e., onde $A_{S_{0}}^{\prime}(E)+A_{B}^{\prime}(E)=0$.

62. Em média, contudo, a alta administração parece ter participações substanciais em unidades monetárias absolutas. Um levantamento recente conduzido por (Wall Street Journal, 13 de agosto de 1974, p. 1) revelou que 0 valor médio das participações em ações de 826 CEO s em suas empresas no fim de 1973 era de $\$ 557.000$ e de $\$ 1,3$ milhões no fim de 1972.

63. Esses efeitos de diversificação podem ser substanciais. Evans e Archer (1968) demonstram que, na média da Bolsa de Valores de N ova York, títulos de aproximadamente $55 \%$ do risco total (como mensurado pelo desvio padrão dos retorno do portfólio) podem ser eliminados por meio de uma of simples estratégia de dividir igualmente os ativos de uma pessoa entre 40 títulos selecionados al eatoriamente.

64. 0 recente trabalho de Myers (1975), que considera as oportunidades futuras investimento como opções e investiga os efeitos sobre o incentivo da existência de capital de terceiros na situação em que uma seqüência de decisões de investimento são tomadas constitui um outro passo importante na investigação dos aspectos multiperíodo do problema do agência e da teoria da firma. 
65. Becker e Stigler (1972) analisam um caso especial deste problema, envolvendo a utilização de direitos não garantidos de pensões para ajudar a corrigir essa manobra final na garantir o cumprimento da lei.

66. Pelo nosso colega David Henderson.

67. Isso também sugere que alguns detentores de capital de terceiros externo podem se proteger da "exploração" por parte do administrador pela compra de uma parcela do capital próprio total igual à sua propriedade parcial do capital de terceiros. Todos os detentores de capital de terceiros, é claro, não são possibilitados de fazê-lo a não ser que o administrador também o faça. Além disso, uma regra de investimento como essa restringe as opções de portfólio dos investidores e, desta foram, imporia custos se rigorosamente seguida. Assim, os custos de agência também não serão eliminados dessa maneira.

68. Considere a situação na qual os detentores de obrigações têm o direito, no caso de falência, de demiti-lo e, desta forma, de descontinuar os retornos futuros de qualquer capital humano específico ou rendimentos que ele possa estar recebendo.

69. Veja Fama (1970) para um levantamento da literatura sobre esses "mercados eficientes".

70. Veja Jensen (1969) para um exemplo dessa evidência e para referências.

71. Ignorando quaisquer elementos de consumo puro na demanda pela análise de títulos.

72. Mais uma vez, ignorando o valor dos elementos de consumo puro na demanda pela análise de títulos.

\section{REFERÊNCIAS}

ALCHIAN, A .A., The basis of some recent advances in the theory of management of the firm, Journal of Industrial Economics, v. 14, n. 4, p. 30-44, 1965

ALCHIAN, A. A. Corporate management and property rights. In: Economic policy and the regulation of securities. Washington, DC: American Enterprise Institute 1968.

ALCHIAN, A. A. 1974, Some implications of recognition of property right transactions costs. In: INTERLAKEN CONFERENCE ON ANALYSIS AND IDEOLOGY, 10, 1974.

ALCHIAN, A .A; ALLEN, W.R. Exchange and production: theory in use. Belmont, CA: Wadsworth, 1969.

ALCHIAN, A.A.; DEMSETZ, H. Production, information costs, and economic organization. American Economic Review v. 62, n. 5, p. 777-795, 1972.

ALCHIAN, A.A.; KESSEL, R.A. Competition, monopoly and the pursuit of pecuniary gain. In: NATIONAL BUREAU OF ECONOMIC RESEARCH. Aspects of labor economics. Princeton, NJ: Princeton University Press, 1962.
ARROW, K.J., Control in large organizations, Management Science, v.10, n. 3 , p. $397-408.1963 / 4$

ARROW, K.J., The role of securities in the optimal allocation of risk bearing, Review of Economic studies, v. 31, n. 86, p. 91-96, 1964.

ATKINSON, T.R. Trends in corporate bond quality. In: NATIONAL BUREAU OF ECONOMIC RESEARCH. Studies in corporate bond finance 4, New York: National Bureau of Economic Research, 1967.

BAUM OL, W.J. Business behavior, value and growth. N ew York: Macmillan, 1959.

BECKER, G. The economics of discrimination. Chicago, IL: University of Chicago Press, 1957.

BECKER, G.S.; STIGLER, G.J. 1972. Law enforcement, corruption and compensation of enforcers. In: CONFERENCE ON CAPITALISM AND FREEDOM, 1972.

BENSTON, G. The impact of maturity regulation on high interest rate lenders and borrowers. Journal of Financial Economics, v. 4, n. 1, p. 23-49, 1977.

BERHOLD, M. A theory of linear profit sharing incentives. Quarterly Journal of Economics, v. 85, n. 3, p. 460-482, 1971.

BERLE Jr., A.A.; MEANS, G.C. The modern corporation and private property. New York: Macmillan, 1932.

BLACK, F. SCHOLES, M. The pricing of options and corporate liabilities. Journal of Political Economy, v. 81, n. 3, p. 637-654, 1973.

BLACK, F.; MILLER, M.H; R.A. POSNER, 1974. An approach to the regulation of bank holding companies. Chicago, IL: University of Chicago, 1974. Mimeo.

BRANCH, B. Corporate objectives and market performance. Financial M anagement. v. 2. n. 2, p. 24-29, 1973.

COASE, R. H. The nature of the firm, Economica, v.4, n. 16, p. 386-405, 1937

COASE, R.H. The Federal Communications Commission. Journal of Law and Economics, v. 2, n. , p. 1-40, 1959.

COASE, 1960. The problem of social cost. Journal of Law and Economics, v. 3, p. 1-44

COASE, R.H. Discussion. American Economic Review, v. 54, n. 3, p. 194-197, 1964.

CYERT, R.M.; HEDRICK, C. L. Theory of the firm: past, present and future; an interpretation. Journal of Economic Literature, v. 10, n. 2, p. 398-412, 1972.

CYERT, R.M.; MARCH, J.G. A behavioral theory of the firm. Englewood Cliffs, NJ: Prentice Hall, 1963.

DE ALESSI, L. Private property and dispersion of ownership in large corporations. Journal of Finance, v. 28, n. 4, p. 839-851, 1973. 
DEBREU, G. Theory of value. New York: Wiley, 1959

DEMSETZ, H. Toward a theory of property rights. American Economic Review, 57, n. 2, p. 347-359, 1967.

DEMSETZ, H. Information and efficiency: another viewpoint. Journal of Law and Economics, v. 12, n.1, p. 1-22, 1969.

DIAMOND, P.A. The role of a stock market in a general equilibrium model with technological uncertainty. American Economic Review 57, n.2, p. 759-776, 1967.

EVANS, J.L; ARCHER, S.H. Diversification and the reduction of dispersion: an empirical analysis. Journal of Finance, v. 23, n. 5, 1968.

FAMA, E.F. Efficient capital markets: a review of theory and empirical work. Journal of Finance, v. 25, n. 2, 1970a.

FAMA, E.F. Multiperiod consumption-investment decisions. American Economic Review, 66, n. 4 1970b.

FAMA, E.F. Ordinal and measurable utility. In: JENSEN, M.C. (Ed), Studies in the theory of capital markets. N ew York: Praeger, 1972.

FAMA, E.F.; MILLER, M. The theory of finance. New York: Holt, Rinehart and Winston, 1972.

FRIEDMAN, M. The social responsibility of business is to increase its profits, N ew York Times Magazine, 13.09.1970.

FURUBOTN, E.G.; PEJOVICH, S. Property rights and economic theory: a survey of recent literature. Journal of Economic Literature, v. 10, n. 4, p. 1137-1162, 1972.

GALAI, D.; MASULIS, W. The option pricing model and the risk factor of stock. Journal of Financial Economics, v. 3, n. 1/2, p. 53-82, 1976.

HAKANSSON, N.H., The superfund: efficient paths toward a complete financial market. University of California, Berkeley, CA, 1974. Research Program in Finance Working Papers, n. 25/1974a.

HAKANSSON, N.H. O rdering markets and the capital structures of firms with illustrations. University of California, Berkeley, CA, 1974. Institute of Business and Economic Research Working Paper, n. 24, 1974b.

HECKERM AN, D.G., Motivating managers to make investment decisions. Journal of Financial Economics, v. 2, n. 3, p. 273-292, 1975.

HIRSHLEIFER, J. On the theory of optimal investment decisions. Journal of Political Economy, v. 66, p. 329-352, 1958.

HIRSHLEIFER, J. Investment, interest, and capital. Englewood Cliffs, NJ: Prentice-Hall, 1970.

JEN SEN, M.C. Risk, the pricing of capital assets, and the evaluation of investment portfolios. Journal of Business, v. 42, n. 2, p.167-247, 1969.

JEN SEN, M.C. 1974, Tests of capital market theory and implications of the evidence. University of Rochester, Rochester, NY, 1974. Graduate School of Management Working Paper Series, n.7414/1974.
JENSEN, M.C.; LONG, J.B. Corporate investment under uncertainty and Pareto optimality in the capital markets. Bell Journal of Economics, v. 3, n. 1, p. 151-174, 1972.

JENSEN, M.C.; W. H. MECKLING, 1976. Can the corporation survive? University of Rochester, Rochester, NY, 1976. Center for Research in Government Policy and Business Working Paper, n. PPS 76-4/1976.

KLEIN, W.A. Legal and economic perspectives on the firm. University of California, Los Angeles, CA, 1976. Mimeo.

KRAUS, A. LITZENBERGER, R. A state preference model of optimal financial leverage. Journal of Finance, v. 28, n. 4, p. 911-922, 1973.

LAMER, R.J, Management control and the large corporation. New York: Dunellen, 1970.

LINTNER, J. Security prices, risk, and maximal gains from diversification. Journal of Finance, v. 20, n. 4. p. 587-616, 1965.

LLOYD-DAVIES, P. Risk and optimal leverage. University of Rochester, Rochester, NY, 1975. Mimeo.

LONG, J.B. Wealth, welfare, and the price of risk. Journal of Finance, $v$. 27, n. 2, p. 419-433, 1972.

LONG JR, J.B. Discussion. Journal of Finance, v. 39, n. 12, p. 485-488, 1974.

MACHLUP, F. Theories of the firm: marginalist, behavioral, managerial. American Economic Review, v. 57, n. 1, p. 1-33, 1967.

MANNE, H.G. The 'higher criticism' of the modern corporation. Columbia Law Review, v. 62, n. 3, p. 399-432, 1962

MANNE, H.G. Mergers and the market for corporate control. Journal of Political Economy, v. 73, p. 110-120, 1965.

MANNE, H.G. O ur two corporate systems: law and economics. Virginia Law Review, v. 53, n. 2, p. 259-284, 1967.

MANNE, H.G. The social responsibility of regulated utilities. Wisconsin Law Review, v. 5, n. 4, p. 995-1009, 1972.

MARRIS, R. The economic theory of managerial capitalism. Glencoe, IL: Free Press of Glencoe, 1964.

MASON, E.S. The corporation in modern society. Cambridge, MA: Harvard University Press, 1959.

MCMANUS, J.C. The costs of alternative economic organizations. Canadian Journal of Economics, v. 8, n. 3, p. 334-350, 1975.

MECKLING, W. H. Values and the choice of the model of the individual in the social sciences. Schweizerische Zeitschrift fur Volkswirtschaft und Statistik, 1976.

MERTON, R.C. The theory of rational option pricing. Bell Journal of Economics and M anagement Science, v. 4, n. 1, p. 141-183, 1973 
MERTON, R.C. On the pricing of corporate debt: the risk structure of interest rates. Journal of Finance, v. 29, n. 2, p. 449-470, 1974.

MERTON, R.C.; SUBRAHMANYAM, M.G. The optimality of a competitive stock market. Bell Journal of Economics and M anagement Science, $v .5$, n. 1, p. 145-170, 1974.

MILLER, M.H.; MODIGLIANI, F. Some estimates of the cost of capital to the electric utility industry, 1954-57. American Economic Review, v. 56, p. 333-391, 1966.

MODIGLIANI, F.; MILLER, M.H. The costs of capital, corporation finance, and the theory of investment. American Economic Review, v. 48, n. 3, p. 261-297, 1958.

MODIGLIANI, F.; MILLER, M.H. Corporate income taxes and the cost of capital: a correction, American Economic Review June, v. 53, n. 3, p. 433-443, 1963.

MONSEN, R.J.; DOWNS, A. A theory of large managerial firms. Journal of Political Economy, v. 73, p. 221-236, 1965.

MYERS, S.C. A note on the deter minants of corporate debt capacity. London Graduate School of Business Studies, London, 1975. Mimeo.

PENROSE, E. The theory of the growth of the firm. N ew York: Wiley,1958.

PRESTON, L.E. Corporation and society: the search for a paradigm. Journal of Economic Literature, v. 13, n. 2, p. 434-453, 1975.

ROSS, S.A. The economic theory of agency: the principals problems. American Economic Review, v. 62, n. 2, p. 134-139, 1973.

ROSS, S.A. The economic theory of agency and the principle of similarity. . In: BALCH, M.D. e outros (Ed), Essays on economic behavior under uncertainty. Amsterdam: North-H olland, 1974a.

ROSS, S.A., 1974b. Options and efficiency, University of Pennsylvania, Philadelphia, PA, 1974. Rodney L. White Center for Financial Research Working Paper, n. 3-74/1974b.

RUBINSTEIN, M. A discrete-time synthesis of financial theory, Parts I and II. University of California, Berkeley, CA, 1974. Institute of Business and
Economic Research Working Papers n. 20 e 21/1974.

SCITOVSKY, T. A note on profit maximisation and its implications. Review of Economic Studies, v. 11, n. 1, p. 57-60, 1943.

SHARPE, W.F. Capital asset prices: a theory of market equilibrium under conditions of risk. Journal of Finance, v. 19, n. 3, p. 425-442, 1964.

SHUBIK, M. A curmudgeon's guide to microeconomics. Journal of Economic Literature, v. 8, n. 2, p. 405-434, 1970.

SILVER, M.; AUSTER, R. Entrepreneurship, profit and limits on firm size. Journal of Business, v. 42, n. 3, p. 277-281, 1969.

SIMON, H.A. A behavioral model of rational choice. Quarterly Journal of Economics, v. 69, n.1, p. 99-118, 1955.

SIMON, H.A. Theories of decision making in economics and behavioral science. American Economic Review, v. 49, n. 3, p. 253-283, 1959.

SMITH, A. The wealth of nations. New York: Modern Library, 1937.

SMITH, C. Option pricing: a review. Journal of Financial Economics, v. 3 , n. 1/2, p. 3-52, 1976.

WARNER, J.B. Bankruptcy costs, absolute priority, and the pricing of risky debt claims. Journal of Financial Economics, v, 4, p. 239-276, 1977.

WILLIAMSON, O.E. The economics of discretionary behavior: managerial objectives in a theory of the firm. Englewood Cliffs, NJ: Prentice-Hall, 1964.

WILLIAMSON, O.E. Corporate control and business behavior. Englewood Cliffs, NJ: Prentice-Hall, 1970.

WILLIAMSO N, O.E. M arkets and hierarchies: analysis and antitrust implications. New York: The Free Press, 1975.

WILSON, R. The theory of syndicates. Econometrica, v. 36, n. 1, p. 119-132, 1968.

WILSO N, R. La decision: Agregation et dynamique des orders de preference. Paris :Editions du Centre National de la Recherche Scientifique, 1969.

\section{Michael C. Jensen}

Professor da Havard Business School, Harvard University

Doutor em Economia pela Universidade de Chicago

Interesses de pesquisa nas áreas de teoria da agência e estrutura de propriedade

E-mail: mjensen@hbs.edu

Endereço: Harvard University, Graduate School of Business Administration, Baker Library

265, Soldiers Field, Boston, M A 02163

\section{William H. Meckling (in memoriam)}

Ex-professor da Graduate School of Business Administration, University of Rochester, Rochester 